\title{
Review Article \\ Current Overview of Allergens of Plant Pathogenesis Related Protein Families
}

\author{
Mau Sinha, Rashmi Prabha Singh, Gajraj Singh Kushwaha, Naseer Iqbal, \\ Avinash Singh, Sanket Kaushik, Punit Kaur, Sujata Sharma, and Tej P. Singh \\ Department of Biophysics, All India Institute of Medical Sciences, Ansari Nagar, New Delhi 110029, India \\ Correspondence should be addressed to Sujata Sharma; afrank2@gmail.com and Tej P. Singh; tpsingh.aiims@gmail.com
}

Received 22 October 2013; Accepted 17 December 2013; Published 16 February 2014

Academic Editors: B. Cardaba and A. J. Chauhan

Copyright (C) 2014 Mau Sinha et al. This is an open access article distributed under the Creative Commons Attribution License, which permits unrestricted use, distribution, and reproduction in any medium, provided the original work is properly cited.

Pathogenesis related (PR) proteins are one of the major sources of plant derived allergens. These proteins are induced by the plants as a defense response system in stress conditions like microbial and insect infections, wounding, exposure to harsh chemicals, and atmospheric conditions. However, some plant tissues that are more exposed to environmental conditions like UV irradiation and insect or fungal attacks express these proteins constitutively. These proteins are mostly resistant to proteases and most of them show considerable stability at low $\mathrm{pH}$. Many of these plant pathogenesis related proteins are found to act as food allergens, latex allergens, and pollen allergens. Proteins having similar amino acid sequences among the members of PR proteins may be responsible for crossreactivity among allergens from diverse plants. This review analyzes the different pathogenesis related protein families that have been reported as allergens. Proteins of these families have been characterized in regard to their biological functions, amino acid sequence, and cross-reactivity. The three-dimensional structures of some of these allergens have also been evaluated to elucidate the antigenic determinants of these molecules and to explain the cross-reactivity among the various allergens.

\section{Introduction}

Plants are one of the major sources of allergens which elicit allergenic response by immunoglobulin E (IgE) mediated allergies $[1,2]$. These allergens may diffuse into the body from the upper respiratory tract or enter the body through intake of vast range of plant food or may cause external skin irritations [3-5]. Allergens present primarily in pollens, spores, and other plant associated products are responsible for symptoms like rhinoconjunctivitis, asthma, edema, urticarial, and anaphylaxis [6-8]. Allergens ingested as food result in responses like pruritus and swelling of lips, tongue, and soft palate, often accompanied by mild laryngeal symptoms as a sensation of tightness, itching, cough, gastrointestinal symptoms, rhinitis, asthma, cutaneous reactions, and more severe systemic anaphylaxis [9-12]. Some plant derived allergens result in contact dermatitis mostly in skin like itchy fingers, skin irritations, and so forth $[13,14]$. The most widespread groups of plant allergens that are reported belong to the seed storage proteins, structural proteins, and pathogenesis related (PR) proteins [15-17].
Allergens are assigned names based on their accepted taxonomic nomenclature with the first three letters designating their genus and followed by the first letter of the species and an Arabic number denoting the order of the identification. The allergenicity of the protein is mostly dependent on the structural motifs present in the allergens which act as the allergenic determinants or the epitopes that are responsible for binding to $\mathrm{B}$ and $\mathrm{T}$ cells. $\mathrm{B}$ cell epitopes are mostly discontinuous motifs forming conformational epitopes whereas $\mathrm{T}$ cell epitopes are linear and continuous $[18,19]$. It has been found that allergens from diverse species possess similar structural motifs that can be identified by the antibodies resulting in IgE cross-reactivity.

\section{Plant Pathogenesis Related Proteins}

Plant pathogenesis related (PR) proteins are generally induced by various types of pathogens such as viruses, bacteria, and fungi [20-22]. Some of these proteins are also expressed in response to some chemicals that act in a similar 
way as pathogen infection $[23,24]$. However, some of the PR proteins are constitutively expressed in some organs or during certain developmental stages $[25,26]$. They are regarded as PR-like proteins because of their sequence homology. However, some PR-like proteins are found to be strongly induced by infections and hence they are also designated mostly as PR proteins [27].

PRs were first identified from tobacco leaves (Nicotiana tabacum) infected with tobacco mosaic virus and later have been detected in numerous plants of different species [28]. They exhibit distinct biochemical characteristics which are necessary when the plant is under pathogenic infections or any unwanted stress. They are generally low-molecular weight proteins in the range 6 to $43 \mathrm{kDa}$, stable at low $\mathrm{pH}$ $(<3)$, and are protease resistant which helps them survive in the harsh conditions like the vacuolar compartment, cell wall, or intercellular spaces [20]. Depending on their isoelectric points, PR proteins are either acidic or basic and are also found to be either vacuolar or apoplastic [29]. The acidic forms of PR proteins are mostly secreted to the extracellular space and the basic forms are transported to the vacuole by a signal located at the C-terminus [30]. However, such localization cannot be generalized for all PR proteins except in the case of certain tobacco PR family. Currently, PRs are found to be localized in almost all plant organs including leaves, stems, roots, and flowers, though maximum abundance of these proteins is found in the leaves [29].

Usually, upregulation of gene expression during pathogen attack takes place by various signaling molecules like salicylic acid [23, 31, 32] and reactive oxygen species [33] which mediate the expression of acidic PR genes. Induction of basic PR genes is mediated by gaseous phytohormone ethylene and methyl jasmonate [24]. Apart from various environmental factors that trigger the synthesis of these PR proteins, their expressions are also dependent on certain internal developmental stimuli of the plant.

Originally 5 groups of PR proteins have been identified [34] but gradually with the increasing identification of new PR proteins, presently, 17 families of PR proteins are recognized based on their amino acid sequence similarities, enzymatic activities, or other biological properties and numbered in the order in which they were discovered (Table 1) $[29,35$, 36]. In spite of their common name, these proteins display a great diversity in species specificity and in the mechanism of action and do not share any structural relationship among themselves.

PR proteins exhibit multiple functions within the plant. Most PRs exhibit antifungal activity $[37,38]$ though antibacterial, insecticidal, nematicidal, and antiviral activity of some of the PR proteins have also been reported [39, 40]. Some of the PR proteins have enzymatic functions like $\beta-1,3$ glucanase [41] or chitinase activities [42]; some including defensins [43] and lipid transfer proteins [44] have membrane permeabilizing effect. PR proteins thus have crucial function in disease resistance, seed germination, and plants facilitation to adapt to the environmental stress.

Apart from PR proteins, plants under pathogen attack produce other families of proteins having defensive action like PR proteins. Two $\alpha$-amylases are found to be induced in tobacco upon TMV infection [45]. Polygalacturonase inhibitor proteins (PGIPs) are produced by pathogen infection and stress-related signals in plants that can inhibit fungal endopolygalacturonases [46]. Others include cell wall hydroxyproline-rich glycoproteins [47] and lipoxygenases [48]. Certain plant storage proteins, like 2 S-albumins, lectins, vicilins, glycine-rich proteins, and so forth, accumulate in storage vacuoles inside plant cells and perform essential roles as antimicrobial agents in response to pathogen attack $[49,50]$. Ribosome-inactivating proteins (RIPs), cysteinerich peptides, and so forth are also expressed by plants as antimicrobial molecules but are not induced by any pathogen attack $[51,52]$.

\section{Plant PR Proteins and Allergenicity}

In the recent years, a variety of $\mathrm{PR}$ proteins and their homologues causing allergenicity in humans have been isolated and characterized [53-56]. The size, stability, and resistance to proteases along with hydrolytic and membranepermeabilizing ability in some make these proteins excellent candidates to elicit allergenic response [53]. Moreover, PR proteins are mostly associated with high degree of crossreactivity because of structural similarity among some of the major proteins. Many patients allergic to one form of allergen like pollen also display allergic symptoms after ingesting some other allergens like certain fresh fruit, vegetable, or nut [57-59]. Thus, IgE antibodies originally produced in response to a particular allergen sensitization recognize comparable epitopes which are present on the surface of other plant proteins. Hence, reexposure to homologous plant allergens induces an allergic reaction in already sensitized individuals. Some of the common allergic syndromes like pollen-related food syndrome, latex-fruit syndrome, or the birch-mugwortcelery-spice syndrome are associated among the different PR proteins [60-62].

It has also been observed that plants growing under different conditions have varied levels of expression of the allergenic PR proteins and their homologues [63]. The expression of some of these classes of allergens also shows alterations due to environmental pollutants [55]. Based on sequence characteristics, a number of allergens classified as PR proteins are recognized from PR families 1, 2, 3, 4, 5, 8, 10, and 14 (Table 1) [29]. Thus, evaluating the structure and role of members of these different PR families in allergenicity will help to understand the allergenic cross-reactivity and will explain the differences in the frequency of sensitization and severity of allergenicity in sensitized individuals.

3.1. PR-1 Family Allergens. PR-1 proteins were first found to be expressed in tobacco in response to tobacco mosaic virus (TMV) infection having 14 to $17 \mathrm{kDa}$ molecular weights [64]. Later, homologues of tobacco PR-1 proteins have been identified in barley, tomato, maize, rice, and so forth [6568]. These widely distributed proteins of plant kingdom have antifungal activity at the micromolar level against a number of plant pathogenic fungi [66], but their mechanism of action 
TABLE 1: Different PR-protein families and allergens identified.

\begin{tabular}{|c|c|c|c|}
\hline Family & Proteins & Functions & Allergens identified with source and allergenic symptoms \\
\hline PR-1 & PR-1 a, PR-1 b, and PR-1 c & Antifungal & Cuc m 3 (muskmelon)_oral allergy syndrome \\
\hline PR-2 & $\beta$-1,3-Glucanases & Cleaves $\beta$-1,3-glucans & $\begin{array}{l}\text { Hev b } 2 \text { (latex) - contact dermatitis } \\
\text { Ole e } 9 \text { (olive)-respiratory allergy } \\
\text { Mus a } 5 \text { (banana) - oral allergy syndrome }\end{array}$ \\
\hline PR-3 & $\begin{array}{l}\text { Chitinase types I, II, IV, V, } \\
\text { VI, and VII }\end{array}$ & Endochitinase & $\begin{array}{l}\text { Pers a } 1 \text { (avocado) - itchy eyes or nose, asthma, swelling, and so forth. } \\
\text { Mus a } 2 \text { (banana) - food allergy like swelling of lips, anaphylaxis, and } \\
\text { so forth }\end{array}$ \\
\hline PR-4 & Chitinase types I and II & Antifungal and chitinase & Hev b 6.01, Hev b 6.02, and Hev b 6.03 (latex) — contact dermatitis \\
\hline PR-5 & Thaumatin-like proteins & Antifungal & $\begin{array}{l}\text { Jun a } 3 \text { (mountain cedar), Cry j } 1 \text { (Japanese cedar), and Cup a } 3 \\
\text { (Arizona cypress) - rhinitis, conjunctivitis, and asthma } \\
\text { Pru av } 2 \text { (cherry), Mal d } 2 \text { (apple), Cap a } 1 \text { (bell pepper), Act d } 2 \\
\text { (kiwi), and Mus a } 4 \text { (banana) - oral allergy syndrome }\end{array}$ \\
\hline PR-6 & $\begin{array}{l}\text { Tomato proteinase } \\
\text { inhibitor I }\end{array}$ & Proteinase inhibitor & - \\
\hline PR-7 & Tomato endoproteinase $\mathrm{P}$ & Endoproteinase & - \\
\hline PR-8 & Cucumber chitinase & Chitinase III & $\begin{array}{l}\text { Hevamine (latex)—contact dermatitis. } \\
\text { Ziz m } 1 \text { (Indian jujube)—oral allergy syndrome } \\
\text { Cof a } 1 \text { (coffee)—eye and airway allergy }\end{array}$ \\
\hline PR-9 & $\begin{array}{l}\text { Tobacco lignin-forming } \\
\text { peroxidase }\end{array}$ & Peroxidase & - \\
\hline PR-10 & $\begin{array}{l}\text { Parsley "PR-1" } \\
\text { Bet v 1, Mal d 1, Api g 1, } \\
\text { and Dau c } 1\end{array}$ & Ribonuclease-like & $\begin{array}{l}\text { Bet v } 1 \text { (birch pollen) - allergic rhinoconjunctivitis and asthma } \\
\text { Pru av } 1 \text { (cherry), Mal d } 1 \text { (apple), Api g } 1 \text { (celery), and Dau c } 1 \\
\text { (carrot)-oral allergy syndrome } \\
\text { Gly m } 4 \text { (soy), Vig r } 1 \text { (mung bean), Cor a } 1 \text { (hazelnut), and Cas s } 1 \\
\text { (chestnut)-oral allergy syndrome }\end{array}$ \\
\hline PR-11 & Tobacco chitinase type $\mathrm{V}$ & Chitinase & - \\
\hline PR-12 & Radish Rs-AFP3 & Defensin & - \\
\hline PR-13 & Arabidopsis THI2.1 & Thionin & - \\
\hline PR-14 & Lipid transfer proteins & $\begin{array}{l}\text { Shuttling of phospholipids } \\
\text { and fatty acids }\end{array}$ & $\begin{array}{l}\text { Par j } 1 \text { (weed)_rhinitis and asthma } \\
\text { Pru p } 3 \text { (peach), Mal d } 3 \text { (apple), Pru av } 3 \text { (cherry), Pru ar } 3 \text { (apricot), } \\
\text { Cor a } 8 \text { (hazelnut), Cas s } 8 \text { (chestnut), and Zea m } 14 \text { (maize)-oral } \\
\text { allergy syndrome }\end{array}$ \\
\hline PR-15 & Barley OxOa & Oxalate oxidase & - \\
\hline PR-16 & Barley OxOLP & Oxalate-like oxidase & - \\
\hline PR-17 & Tobacco PRp27 & Unknown & - \\
\hline
\end{tabular}

is not known. No allergens were reported from PR-1 protein family till 2004. The first evidence of an allergen Cuc $\mathrm{m} 3$ was reported from muskmelon which comprises many pollen allergens, thus delivering the involvement of this plant allergen family in food allergy [69]. Cuc m 3 shows more than $60 \%$ of sequence identity with PR- 1 members from grape and cucumber.

3.2. PR-2 Family Allergens. PR-2 family of proteins are $\beta$-1,3-glucanases (glucan endo-1,3- $\beta$-glucosidases) which are monomeric enzymes having molecular weight around $20-23 \mathrm{kDa}$. These highly regulated enzymes catalyze the hydrolytic cleavage of $\beta$-1,3-glucans abundantly present in plant cell walls [70]. These enzymes function in response to pathogenic attack and are also involved in several physiological and developmental processes, for example, cell division [71], microsporogenesis [72],pollen germination [73], fertilization [74] and seed germination [75], and mobilisation of storage products in the endosperm of cereal grains [76]. These proteins were also induced in response to ozone and ultraviolet B light, mechanical injury, and freezing temperatures [77-79].

The PR-2 proteins are divided into three classes based on amino acid sequence identity, primary structure, cellular localization, and mode of expression [80]. The class I members with approximate size of $33 \mathrm{kDa}$ are basic and localized in the cell vacuole and are found in tobacco, tomato, potato, and other plant species [81]. The class II and class III proteins are acidic proteins with average molecular weights around 34 to $36 \mathrm{kDa}$ secreted into the extracellular space [82]. Antifungal activity has been observed only in class I $\beta$ glucanases. The proteins belonging to class I family have an additional C-terminal extension which is posttranslationally cleaved during intracellular transport and are likely to contain the vacuolar targeting signal [83]. 


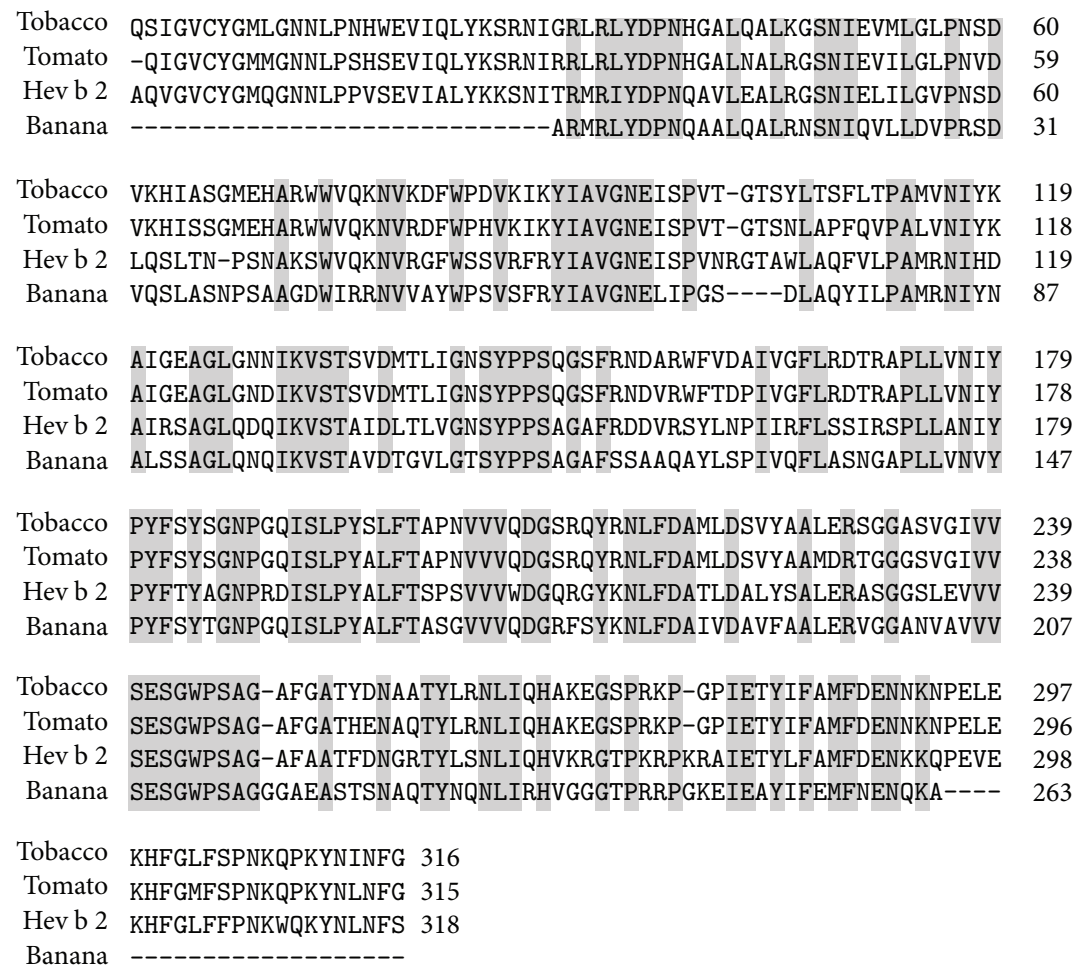

Figure 1: Multiple sequence alignment of $\beta$-1,3-glucanases from tobacco, tomato, banana, and latex (Hev b 2). The identical residues are highlighted in grey.

Some of the allergens having sequence similarity to $\beta-1,3-$ glucanases have been identified. Latex from Hevea brasiliensis contains several allergenic proteins that are involved in allergenicity resulting in symptoms like mild contact urticaria to asthma and anaphylactic reactions that frequently occur during surgical or endoscopic procedures $[84,85]$. One of them is Hev b 2, a $\beta$-1,3-glucanase enzyme that is recognized by IgEs of latex-allergic patients. This protein shares $62.9 \%$ and $64.7 \%$ sequence identities with tobacco and tomato $\beta$ 1,3 -glucanases (Figure 1). This $36 \mathrm{kDa}$ protein is present in different isoforms and with variable glycosylation content $[86,87]$. Both its peptidic and carbohydrate moieties are known to possess allergenic determinants $[88,89]$.

The structure of Hev b 2 adopts a TIM-barrel, $(\alpha / \beta)_{8}$ fold (PDB code: 3EM5). Several IgE binding epitopes have been recognized along the entire amino acid sequence of the major latex allergen Hev b 2 [90] (Figure 2(a)). The amino acid residues residing in the IgE binding epitopic regions are found to be mostly exposed on the surface and the epitopes usually correspond to charged regions on the molecular surface of the protein.

Hevea latex allergy has been found to be associated with hypersensitivity to foods, especially avocado, banana, chestnut, fig, bell pepper, and kiwi, and is termed latex-fruit syndrome [91-93]. The reason for such cross-reactivity is that the proteins expressed in these fruits share very similar overall conformation and charge distribution to those of $\mathrm{Hev}$ b 2 . Hev b 2 has about $60.8 \%$ sequence identity with banana $\beta$-1,3-glucanase, Mus a 5, the expression of which increases to a considerable amount during fruit ripening [94]. Five IgE binding epitopes similar to Hev b 2 have been identified in this protein (Figure 2(b)).

Another PR-2 protein, Ole e 9, has been characterized from olive pollen [95]. The protein is composed of two immunological independent domains: an $\mathrm{N}$-terminal domain with $\beta$-1,3-glucanase activity and a C-terminal domain that binds $1,3-\beta$-glucans. The overall structure of $\mathrm{C}$ terminal domain of Ole e 9 has been found to comprise two parallel $\alpha$-helices, a small antiparallel $\beta$-sheet with two short strands, and a 3-10 helix turn connected with each other by long coil segments (Figure 3 ). Two regions have been identified on the protein surface which are constituted of aromatic residues and have a possible role in sugar binding. Using epitope mapping four IgE epitopes have been characterized on the C-terminal domain of Ole e 9 which are mainly concentrated on the loops and few in secondary structural elements [96].

3.3. PR-3 Family Allergens. Among the seven different classes of chitinases, chitinases of classes I, II, and IV are grouped under PR-3 family proteins. Chitinases hydrolyze the glycosidic bonds in chitin, a component of the cell walls of fungi and exoskeletal elements of some animals [97]. Plant chitinases are monomeric proteins of $25-35 \mathrm{kDa}$ molecular weights and are mostly endochitinases which break the 


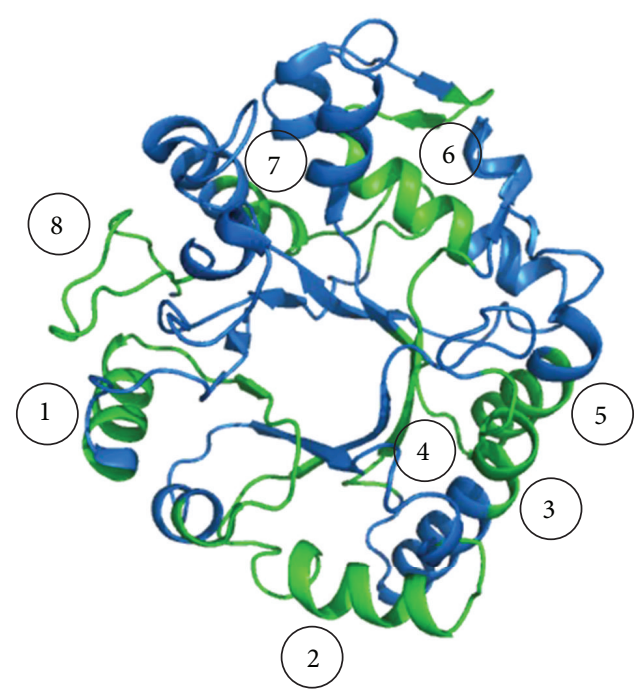

(a)

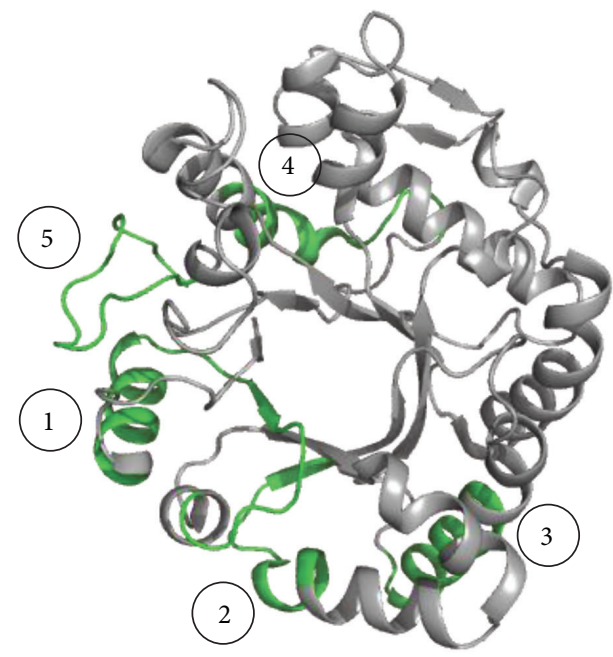

(b)

Figure 2: (a) Overall structure of Hev b 2 showing IgE binding epitopes (in green). (b) Overall structure of $\beta$-1,3-glucanase from banana showing IgE binding epitopes (in green).

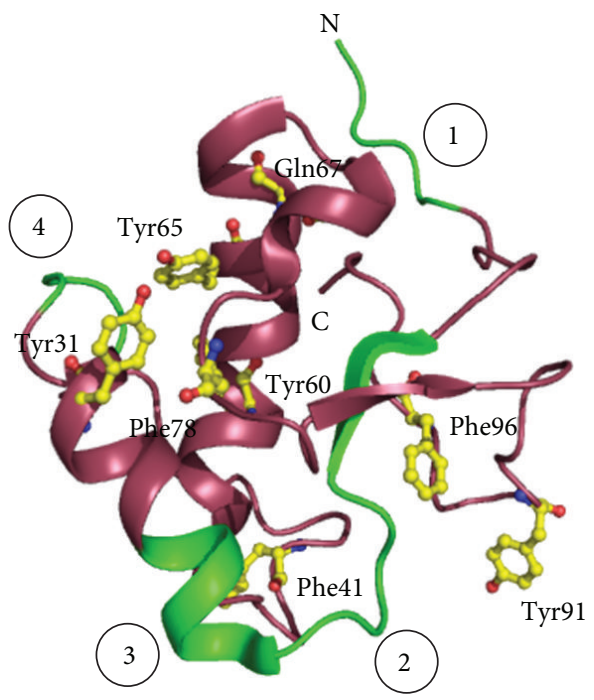

FIgURE 3: Structure of C-terminal domain of Ole e 9 from olive pollen. The four IgE binding epitopes (in green) marked from 1 to 4 are shown. The aromatic residues which form two distinct sugar binding faces are shown in yellow.

chitin within the biopolymer. They produce 2-6 N-acetylglucosamine units and hydrolyze $\beta$-1,4-linkages between the $\mathrm{N}$-acetylmuramic acid and the $\mathrm{N}$-acetylglucosamine of lysozyme.

Some of the class I chitinases found in seed producing plants are basic proteins that are vacuolar and antifungal, whereas the acidic ones are extracellular with little antifungal activity. This class of chitinases contains a cysteinerich 40-amino-acid domain at the $\mathrm{N}$-terminus, the chitin binding hevein domain, a hypervariable domain (which is a proline-rich hinge region), and a catalytic domain [98].
The exact role of the hevein domain is not clear though it is required for chitin binding and for substrate affinity. It is speculated that the chitin-binding domain helps in increasing the efficiency of enzymatic cleavage of the polymer by attaching the catalytic domain onto the substrate. The intracellular localization depends on the presence of a Cterminal vacuolar targeting propeptide. A signal peptide is removed from the mature protein and a target sequence directing the protein to the vacuole is located at the Cterminus.

Class II chitinases having molecular weights of 27 to $28 \mathrm{kDa}$ resemble class I proteins in terms of amino acid sequence, but they lack the N-terminal cysteine-rich hevein domain and the vacuolar target sequence. These enzymes are mainly acidic and extracellular and display $60-65 \%$ sequence similarities to class I chitinases. Some of these members induce antifungal activity in living plant cells rather than killing the invading fungus. Class IV proteins are similar to class I chitinases but are significantly smaller in size due to four major deletions [99].

Some of the major class I chitinase allergens of the PR3 family have been identified from chestnut (Cas s 5) and avocado (Pers a 1) $[100,101]$. Since these proteins are characterized by the presence of a conserved hevein-related structure, patients with previous exposure to latex prohevein or hevein are potential candidates for cross-reaction with these fruits and vegetables [102]. Pers a 1, a $32 \mathrm{kDa}$ endochitinase, exhibits strong antifungal activity [101]. Class I chitinases are also recognized in banana (Mus a 2) with hevein-like domain having IgE binding properties. This protein shares about $74.0 \%$ amino acid sequence identity with Pers a 1 including the hevein-like domain present in both proteins (Figure 4). The stability of the proteins is maintained by the presence of cysteine residues. However, the three-dimensional structures of these proteins have not yet been reported [103]. 
Hevein 1 EQ CGRQAGG KLCPN NLCC SQ WGW CGST 27

Avocado EQ CGRQAGGALCPG GLCC SQFGW CGST SDY CGPT CQSQ C-------- GG VTP SP GGG --- V 50 Banana EQ CGSQAGGAVCPN CLCC SQFGW CGST SDY CGAG CQSQ CSAAG CGG GG PTP PS GGG GSG V 60

Avocado AS LI SQSVFNQML KHRNDAA CQAKGFYTY NAF I AAA NS FNGFA SV G-DTA TRKRE I AAFL 109 Banana AS IV SRS LFD QML L HRNDAA CP A SNFYTY D AF VAAA SA FPGFA AA GGD AD TN KRE VAAFL 120

Avocado AQTSHETTGGWATAPDGPY AWGY CFLKE Q G -- NP PDY CVPT AQWPCAPGKKYYGRGPIQL 167 Banana AQTSHETTGGWATAPDGPY TWGYCFKEE N G GAAG PDY CQQS AQWPCAAGKKYYGRGPIQL $\quad 180$

Avocado SYN YNYGPAGRAIG YDL INN PD A VA TDPVISF KTA LWFWMTPQSPKPSCHNV ITGRWTPS $\quad 227$ Banana SYN FNYGPAGQAIG ADL LGD PD LVA SDATVSF DTA FWFWMTPQSPKPSCHA VATGQWTPS 240

Avocado AADRAAGR L PGYGVITNIINGG IECGKGFN DKVADRIGFYKRY CDLLGVSYG SNLDCYNQ $\quad 287$ Banana ADDQAAGR V PGYGVITNIINGG LECGHGED DRVADRIGFYKRY CDILGVSYG ANLDCYSQ 300

Avocado RSFG VSTNPLAASS 301

Banana RPFGS---------- 305

FIGURE 4: Sequence alignment of chitinase I from avocado (Pers a 1) and banana. The hevein-like domain (matching with sequence of hevein (1-27)) has also been marked in green. The identical residues and the cysteine residues are highlighted in grey and yellow, respectively.

3.4. PR-4 Family Allergens. PR-4 proteins are chitin-binding proteins, having molecular weights around 13 to $14.5 \mathrm{kDa}$. Some of the PR-4 proteins identified are tobacco protein CBP-20 and barley barwin [104, 105]. The common class I chitinases representing this family are prohevein and woundinducible proteins. Prohevein, a cysteine-rich $20 \mathrm{kDa}$ protein from Hevea brasiliensis, is designated as Hev b 6.01 and is one of the major IgE binding allergens in natural rubber latex allergy, especially common in health care workers [106]. It contains 14 cysteine residues that stabilize its tertiary conformation by forming multiple disulphide bridges. After posttranscriptional processing, prohevein generates the $4.7 \mathrm{kDa} \mathrm{N}$-terminal Hev b 6.02 (hevein) and the $14 \mathrm{kDa}$ C-terminal Hev b 6.03 (Figure 5(a)) both of which are allergenic. The former is involved in IgE binding and carries discontinuous B cell epitopes (Figure 5(b)), whereas Hev b 6.03 is responsible for proliferation response and contains human leucocyte antigen, HLA-DR4-binding motifs [107]. Hev b 6.03 shares more than $90 \%$ sequence similarity with wound-inducible proteins like potato stress proteins, WIN1 and WIN2 (Figure 6).

Hevein has significant sequence similarities (about 71.7\%) with chitin-binding proteins of PR-3 and PR-4 families [106] and is one of the reasons of latex allergic patients resulting in food allergies. Hevein is the major cross-reacting allergen with avocado in subjects with latex allergy [108, 109]. The crystal structure of hevein is folded into a series of loops all linked together by four disulfide bonds (Figure 7). An aromatic patch is formed in the central part of the protein by 2 tryptophan and 1 tyrosine residues encircled by 4 glutamate side chains forming a carbohydrate-combining site constituting a conformational epitope [110]. Current studies have shown that hevein is an ideal target for application in latex immunotherapy. Hypoallergenic variants of prohevein have been obtained by site directed mutagenesis in hevein domain which showed attenuated B cell reactivity but retained human T lymphocyte reactivity [111].

The class II chitinases belonging to PR-4 proteins have been identified from tobacco and tomato with sequence similarity to win proteins, yet lacking the chitin-binding domain [112]. Whole or wounded turnips treated with salicylic acid, ethephon, or water resulted in the expression of an $18.7 \mathrm{kDa}$ protein exhibiting appreciable allergenicity that was recognized by IgE of natural rubber latex allergic patients [113].

3.5. PR-5 Family Allergens. PR-5 proteins have high amino acid homology to sweet tasting protein, thaumatin, from the South African berry bush Thaumatococcus daniellii [114] and are known as thaumatin-like proteins (TLPs) though none of these proteins have been reported to have a sweet taste. These proteins were first identified in tobacco leaf extracts when the plant was infected with tobacco mosaic virus [115]. Though TLPs have been mostly observed in leaves of young plants, they are detected in high levels upon biotic or abiotic stress. Osmotin and NP24 proteins from tobacco and tomato, respectively, are homologous to thaumatin and accumulate after osmotic stress [116, 117]. TLPs are also developmentally expressed to a significant amount in flower buds of turnip and overripe fruits of cherries [118, 119].

Based on their molecular weight, proteins of this class are grouped into two types: the first class having molecular weights ranging from 22 to $26 \mathrm{kDa}$ and the other class having molecular weights around $16 \mathrm{kDa}$ due to an internal deletion of 58 amino acids. Generally, they are acidic, basic, or neutral TLPs. Some of these proteins exert antifungal activity possibly 


\section{Prohevein EQC GRQAGGKLC PNNLCCSQWGW C GSTDEYC SPDHNCQSNCKDSGEGVGGGSASNVLATY 60 HLYNSQDHGWDLNAASAYCSTWDANKPYSWRSKYGWTAFC GPVGAHGQSSCGKC LSVTNT 120 GTGAKTTVRIVDQC SNGGLDLDVNVFRQLDTDGKGYERGHITVNYQFVDC GDSFNPLFSV 180 MKSSVIN 187}

(a)

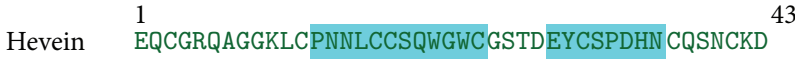

(b)

Figure 5: (a) Amino acid sequence of prohevein showing two allergenic domains obtained after posttranslational cleavage: Hev b 6.02 domain (green) and Hev b 6.03 domain (blue). 14 cysteine residues are highlighted in yellow. (b) Amino acid sequence of hevein showing the IgE binding epitopes highlighted in cyan.

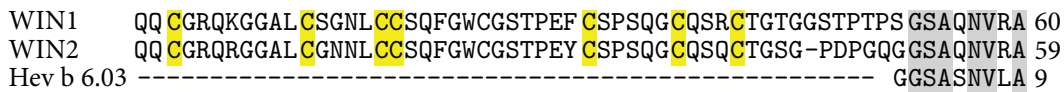

WIN1 TYHIYNPQNVGWDLNAVSAYCSTWDANKP LSWRKKYGWTAF CGPVGPRGRDSCGKCLRVT 120 WIN2 TYHIYNPQNVGWDLNA VSAYCSTWDANKP YAWRSKYGWTAF CGPVGPRGRD SCGKCLRVT 119 Hev b 6.03 TYHLYNSQDHGWDLNA ASAYCSTWDANKP YSWRSKYGWTAF CGPVGAHGQSSCGKCLSVT 69
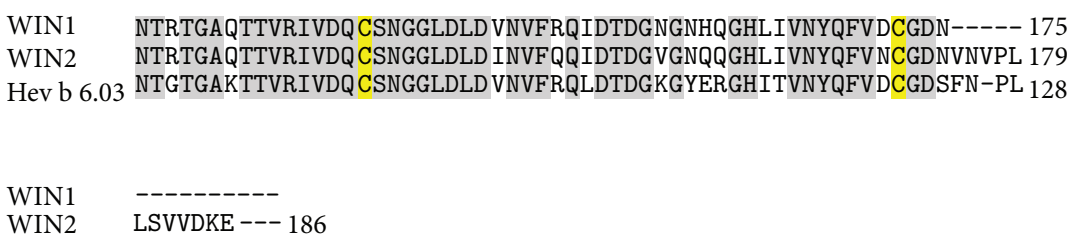

Hev b 6.03 FSVMKSSVIN 138

FIGURE 6: Multiple sequence alignment of Hev b 6.03 with wound inducible proteins WIN 1 and WIN 2. The identical residues are highlighted in grey and the cysteine residues in yellow.

by directly inserting them into the fungal membrane forming a transmembrane pore, eventually resulting in influx of water followed by osmotic rupture. Zeamatin, an antifungal $22 \mathrm{kDa}$ protein that acts by causing membrane permeabilization has been reported, corn seeds [120]. Similar proteins with considerable sequence homology and similar antifungal action are also reported from tobacco, oats, sorghum, and wheat [121].

The allergens of this group are mainly pollen or food derived allergens. Several pollen allergens like Jun a 3 (mountain cedar) [63], Cry j 1 (Japanese cedar) [122], Cup a 3 (Arizona cypress) [123], and Jun v 3 (Eastern red cedar) [124] have been reported. Some of these allergens like Jun a 3 showing variability of expression may contribute to variable allergenicity in different lots of pollen. Four IgE binding epitopes have been predicted in the sequence of Jun a 3: Ala120 to Lys131, Val132 to Lys144, Asn152 to Lys165, and Asn169 to Lys179. Jun a 3 has been found to exhibit crossreactivity with Cry j 1, from Japanese cedar (Cryptomeria japonica) [63]. Cup a 3 from Arizona cypress (Cupressus arizonica) is homologous to Jun a 3 and shows increased allergenicity of pollen from industrialized areas [123].

Allergens of this group belonging to food allergens include Pru av 2 from cherries [125], Cap a 1 from bell pepper $[62,126]$, Mal d 2 from apple [127], Act d 2 from kiwi [128], and Pru p 2 from peach [129]. Pru av 2, the major allergen in cherries, is one of the main causes of oral allergy syndrome and shares considerable sequence identity with Jun a 3. Thaumatin-like protein, associated with baker's respiratory allergy, has been also identified in wheat (Triticum aestivum) [130]. A $24 \mathrm{kDa}$ protein from grapes, homologous to Pru av 2, was reported as a minor allergen [131]. Cap a 1 identified from bell pepper shows an IgE-mediated contact allergy in patients with the mugwort-birch-celery-spice syndrome [62].

The crystal structure of allergenic TLP from banana (Mus a 4) has been characterized [132]. The protein has three distinct domains: the core domain constituted by a $\beta$-sandwich formed by two $\beta$-sheets, an extended $\alpha$-helix domain, and a third domain with a hair-pin segment of two short $\beta$-strands connected to an extended loop. The structure is stabilized by eight disulphide bridges (Figure 8) which are conserved in other thaumatin-like molecules. A central cleft comprising acidic residues Glu83, Asp96, Asp101, and Asp181 imparts a strong electronegative character. Twelve highly exposed flexible linear epitopes for IgE binding have been speculated in banana TLP. Pru av 2 (PDB: 2AHN) and Mal d 2 (PDB: 3ZS3) have similar overall three-dimensional structure, conserved cysteine residues (Figure 9), and share about $72.9 \%$ sequence identity with each other. 


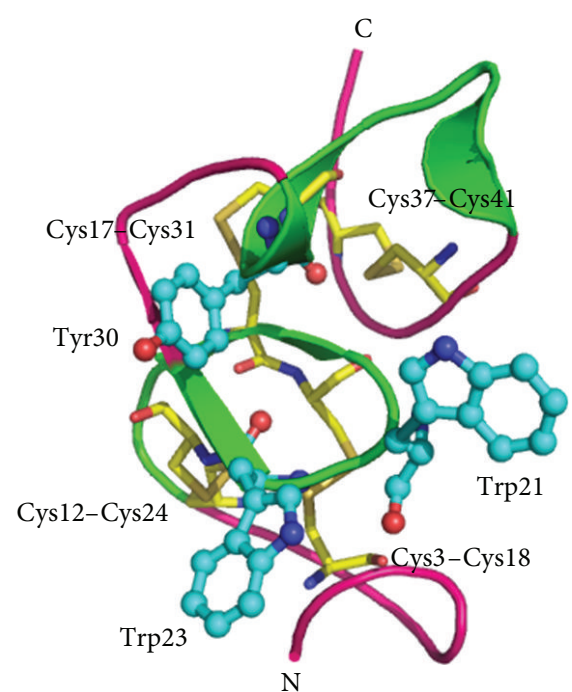

Figure 7: Overall structure of Hev b 6.02 (hevein) showing IgE binding epitopes (in green). Trp21, Trp23, and Tyr30 form an aromatic patch in the conformational epitope. The four disulphide linkages are shown in yellow.

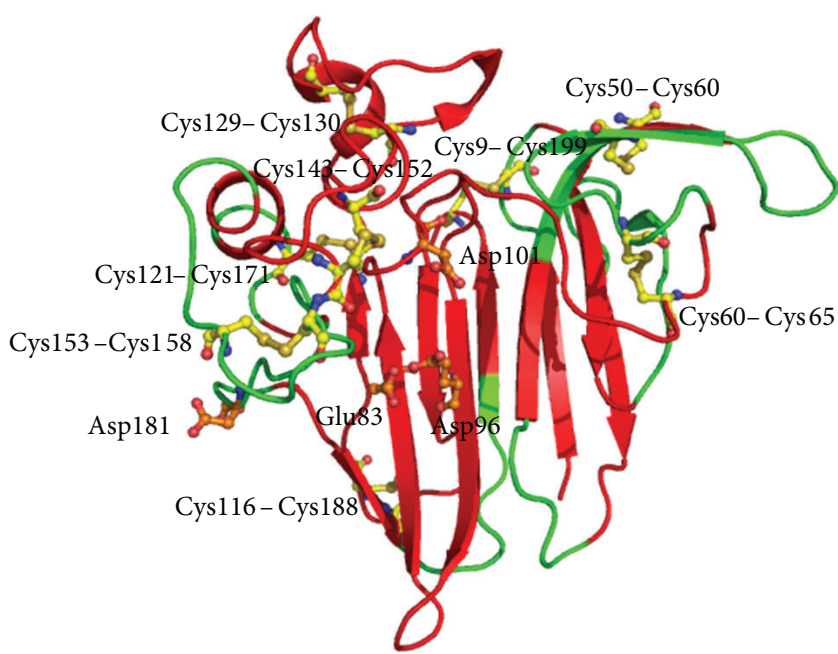

FIgURE 8: Three-dimensional structure of Banana TLP. Eight disulphide bridges and the acidic residues, Glu 83, Asp96, Asp101, and Asp111 are shown. Twelve amino acid stretches are marked in green.

Osmotin has been used in production of transgenic crops because of its ability in permeabilizing the plasma membrane and dissipating the membrane $\mathrm{pH}$ gradient of the fungal species [133]. However, osmotin was identified as a potential allergen and showed cross-reactivity with allergens from tomato and apple [134]. Three possible antibody recognition sites have been speculated in osmotin and validated by in vitro experiments [135].

3.6. PR-8 Family Allergens. PR-8 proteins comprise chitinases belonging to class III type having lysozyme activity [136]. One of the major latex proteins, representing this group, is hevamine (Hev b 14) which displays both lysozyme and chitinase activity. It is a $30 \mathrm{kDa}$ basic chitinase from lutoid bodies of the latex of Hevea brasiliensis belonging to the family 18 glycosyl hydrolases and has been identified as an allergen present in latex products [137]. Hevamine plays an important role in the self-defense of the rubber tree against pathogenic fungi. However, unlike lysozyme, hevamine cleaves peptidoglycan between the C-1 of N-acetyl glucosamine and the C- 4 of $\mathrm{N}$-acetylmuramate.

The amino acid sequence of hevamine shows significant similarity to those of other chitinases/lysozymes from plants and fungi, while there is a lower similarity to chitinases from bacteria, insects, and viruses. The structure of hevamine has a single TIM-barrel $(\beta \alpha)_{8}$ fold with active site residues Asp125, Glu127, and Tyr183 and represents a new class of polysaccharide-hydrolyzing enzymes (Figure 10). The substrate specificity of this protein resides in the loops following the barrel strands that form the substrate binding site. The protein has the two family 18 consensus regions roughly corresponding to the third and fourth barrel strands [138]. Hevamine has been found to be one of the major latex allergens having IgE binding characteristics prevalent mainly in the health care workers of Taiwan $[139,140]$. However, the details of antigenic determinants and their role in allergenicity are still unknown.

A similar class III chitinase, Ziz m 1, had been identified in Indian jujube (Ziziphus mauritiana) as one of the major allergens having IgE cross-reactivity with the latex allergen [141]. Two stretches of residues from Asn72 - Glu86 and from Val292 - Pro320 are the possible IgE binding epitopes characterized in Ziz m 1 [142]. Recent reports suggest that this chitinase can stimulate multiple cytokines, mainly interleukin-13, from peripheral blood mononuclear cells of latex fruit allergic patients [143]. Another chitinase III protein, Cof a 1 having allergenic potential, has been identified in coffee (Coffea arabica) [144].

3.7. PR-10 Family Allergens. PR-10 family proteins are intracellular proteins with unknown enzymatic function. Some proteins of PR-10 family are induced under various stress conditions and act as common allergens $[145,146]$. However, few PR-10 proteins are also constitutively expressed, indicating a role of these proteins in plant development [147]. The members of this family have low molecular weight (around $15-16 \mathrm{kDa}$ ) and are slightly acidic, resistant to proteases, and mostly intracellular and cytosolic $[148,149]$. PR-10 proteins are structurally not related to any other class of PR proteins. Apart from direct function in defense, these proteins are implicated in a general function during overall stress as well as during physiological changes in certain developmental stages [150].

Though this family of proteins is widely studied, the exact function of these proteins is still unclear. Some of these proteins are suggested to have a protective role because they are induced when plants undergo pathogenic or environmental stresses. However, some members are also constitutively expressed indicating a general biological role in plant development associated with these proteins. 


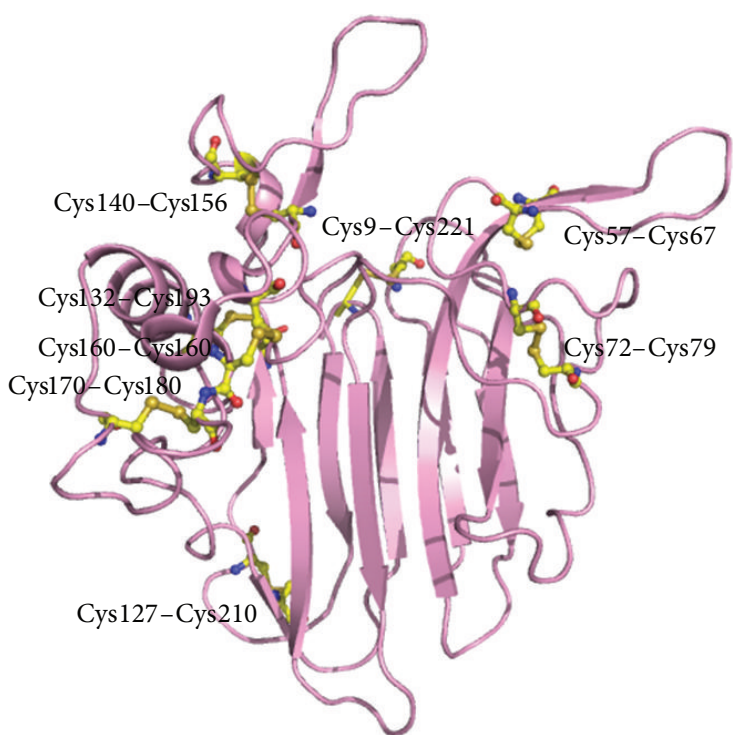

(a)

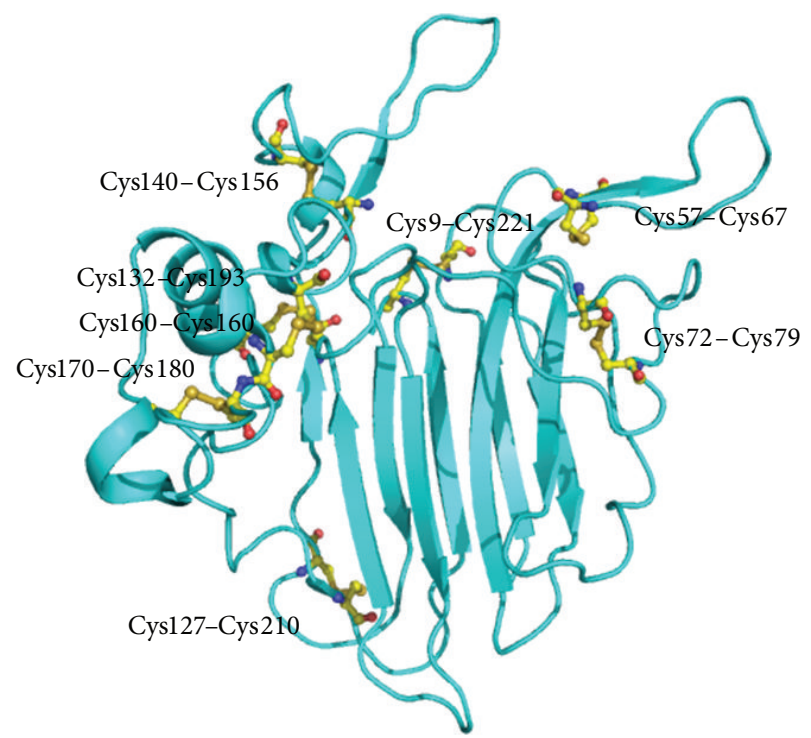

(b)

Figure 9: Three-dimensional structures of (a) Pru av 2 and (b) Mal d 2 showing the conserved cysteine residues.

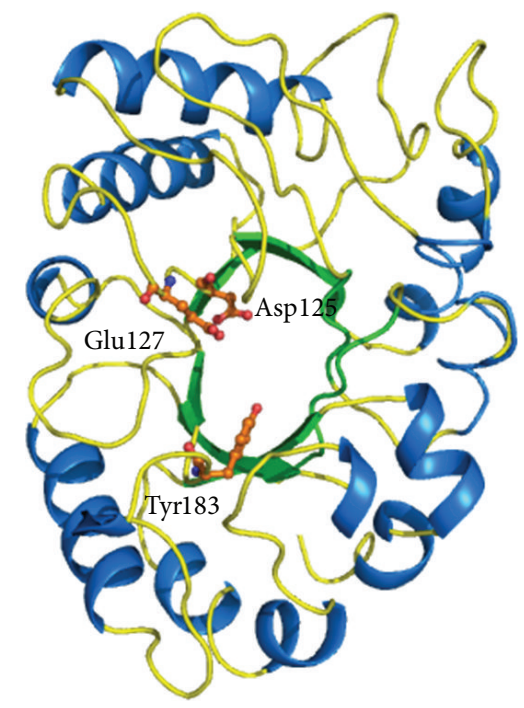

FIgURE 10: Overall structure of hevamine showing TIM barrel domain and the catalytic residues (in orange).

PR-10 proteins are encoded by multigene families which accounts for their multifunctional behavior [151]. Thus PR10 proteins are not responsible for a particular function in the plant system but some of their conserved sequences and their wide spread existence suggest a crucial role of these proteins [152].

This class of proteins was first identified from parsley [153] followed by other common allergens found in birch pollen [154], celery [155], apple [156], and other fruits and vegetables. Of the different PR-10 proteins, birch-related pollen allergens are extensively studied. The $17.5 \mathrm{kDa}$ protein Bet $\mathrm{v} 1$ is mostly responsible for birch pollen allergy and patients allergenic to birch pollens have been found to develop specific IgE towards Bet v 1 [157]. Thirteen different isoforms of Bet $\mathrm{v}$ 1 were identified with the isoform Bet $\mathrm{v}$ la exhibiting the highest and Bet v 11 exhibiting the lowest allergenic activity [158].

Cross-reactivity between Bet v 1 and other food allergens leads to clinical oral allergy syndrome. Several of such allergens homologous to Bet $\mathrm{v} 1$ have been characterized from apple (Mal d1) [156], sweet cherry (Pru av 1) [159], celery (Api g 1) [155], carrot (Dau c 1) [160], peach (Pru p 1) [161], and pear (Pyr c 1) [162]. A sequence comparison of some of these homologous allergens has been done showing a significant sequence similarity of Bet $\mathrm{v} 1$ with the food allergens: about 52.5\% with Mal d 1, 57.8\% with Pru av 1, $39.8 \%$ with Api g 1, 35.9\% with Dau c 1, and about $55.0 \%$ and 56.6\% with Pru p 1 and Pyr c 1, respectively (Figure 11). Cross-reactivity is common when the IgE antibodies, produced originally in response to Bet vl sensitization, recognize similar epitopes present on the surface of these food allergenic proteins [163]. PR-10 proteins responsible for allergenic reactions to legumes are also homologous to Bet $\mathrm{v} 1$ and have been reported from soy (Gly $\mathrm{m}$ 4) [164], peanut (Ara h 8) [165], and mungbean seedlings (Vig $\mathrm{r}$ 1) [166]. Birch pollen allergenicity has been also associated with allergenicity from hazelnuts and chestnuts. Cor a 1 [167] and Cas s 1 [168] are the major allergens responsible for allergenicity from hazelnut and chestnut, respectively. Bet $\mathrm{v}$ 1 shares maximum sequence similarity $(80.5 \%)$ with Cor a 1 (Figure 11).

Bet vl consists of seven stranded $\beta$-sheet structure wrapped around a 25-residue long C-terminal $\alpha$-helix structure both of which are separated by two consecutive helices (Figure 12). A hydrophobic cavity is created by the hydrophobic residues clustering in the interior region with some polar residues pointing into the core [169]. The presence of such an internal cavity suggests a possible role in binding with 
Bet v 1 GVFNYET EATSVIPAARMFKAFILDGDKLVPKVAPQAISSV ENIIGNGGPGT IKKINFPE 60

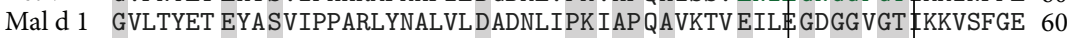
Pru av 1 GVFTYES EFT SEIPPPRLFKAFVL DADNLVPKIAPQA IKHS EIL电GDGGPGT IKKITFGE 60 Api g 1 GVQTHVL ELTSSVSAEKIFQGFVIDVDTVLPKAAPGAYKSV EIK-GDGGPGTLKIITLPD 59 Dau c 1 GAQSHSL EITSSVSAEKIFSGIVLDVDTVIPKAAP GA YKSV EVK-GDGG AGT VRIITLPE 59 Pru $\mathrm{p} 1$ GVFTYES EFTSEIPPPRLFKAFVLDADNLVPK IAPQA IKHS EIL E GDGGPGT IKKITFGE 60 Pyr c 1 GLYTFEN EFT SEIPPPRLFKAFVLDADNLIPKIAPQA IKHA EILEGNGGPGT IKKITFGE 60 Cor a 1 GVFNYET ESTSVIPAARLFKAFIL DGNNLIPKVAPQAVSSV ENV G GNGG PGT IKKITFSE 60

Bet $\mathrm{v} 1$ GFPFKYVKDRVDEVDHTNFKYNYSV TEGGPVGDTL EKISNEIKI VATPD GGCVL KISNKY 120 Mal d 1 GSEYSYVKHKVEGIDKDNFDYSYSL IEGDAISDKI EKISYEIKL VASGSG-SII KNTSHY 119 Pru av 1 GSQYGYVKHKIDSIDKENYSYSYTL IEGDALGDTL EKISYETKL VASPS GGSII KSTSHY 120 Api g 1 GGPITTMTLRIDGVNKEALTFDYSV IDGDILLGFI ES IENHVVL VPTAD GGSIC KTTAIF 119 Dau c 1 GSPITSMTVRTDAVNKEALTYDSTV IDGDILLGFI ESIETHLVV VPTAD GGSIT KTTAIF 119 Pru p 1 GSQYGYVKHKIDSIDKENHSYSYTL IEGDALGDNL EKISYETKL VASPS GGSII KSTSHY 120 $\begin{array}{lll}\text { Pyr c } 1 \text { GSQYGYVKHRVDSIDEASYSYAYTL IEGDALTDTI EKISYEAKL VASGS G-STI KSISHY } & 119\end{array}$ Cor a 1 GSPFKYVKERVEEVDHTNFKYSYTV IEGGPVGDKV EKICNEIKI VAAPD GGSIL KISNKY 120

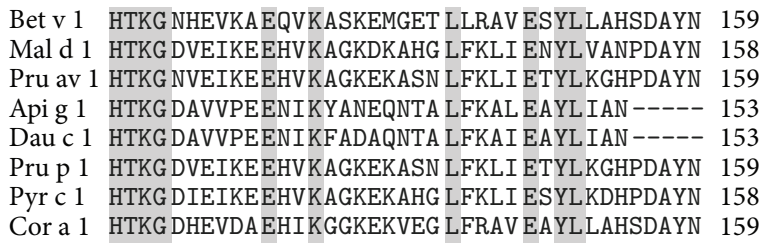

Figure 11: Multiple sequence alignment of birch pollen allergen Bet v 1 with food allergens: Mal d 1, Pru av 1, Api g 1, Dau c 1, Pru p 1, Pyr c 1 , and Cor a 1. The identical sequences are highlighted in grey. The residues of Bet $\mathrm{v} 1$ responsible for IgE binding are marked in green. The nearly conserved glycine rich loop is highlighted in box.

hydrophobic ligands. A glycine rich loop connecting the $2 \beta$-strands, $\beta 2$ and $\beta 3$ is nearly conserved among all the homologous PR-10 proteins. This might have a putative role in lipid binding [170].

Some of the ligands binding to Bet vl with low micromolar affinity such as fatty acids, flavonoids, and cytokinins have been identified. The crystal structure of hypoallergenic isoform Bet $\mathrm{v} 1 \mathrm{l}$ in complex with deoxycholate suggests that Bet $\mathrm{v} 1$ homologous proteins can act as a general plant steroid carrier [171]. It has been evaluated from the crystal structure of this birch pollen allergen in complex with the Fab fragment of a murine monoclonal IgG antibody (BV16), that the centrally located residue Glu45 is critical for antibody recognition and forms two hydrogen bonds with the heavy-chain variable region of the Fab fragment [172]. A conformational epitope containing amino acid residues from Glu42 to Thr52 (which also contains the glycine rich loop) and additional dispersed amino acids Arg70, Asp72, His76, Ile86, and Lys97 has been identified to be responsible for binding to antibody (Figure 12).

The secondary structure and the tertiary fold of Pru av 1, Api g 1, and Dau c 1 are identical to Bet vl [173]. They have a large internal hydrophobic cavity that can interact with hydrophobic ligands and are important for physiological functions. The hydrophobic cavity is large enough to accommodate two such molecules. Binding studies of various phytosteroids to Pru av 1 suggest similar interactions like Bet $\mathrm{v} 1$. Since both of these proteins have high level of sequence

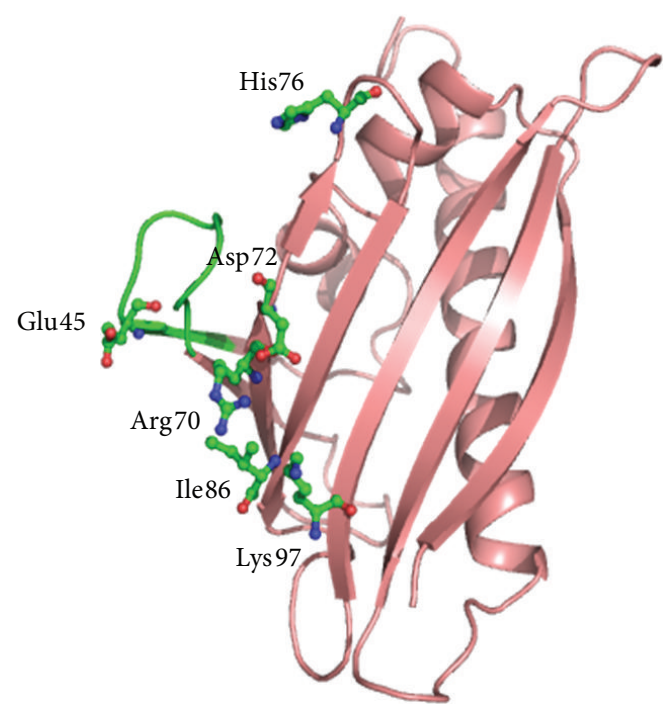

Figure 12: Overall structure of Bet $\mathrm{v} 1$ protein showing the conformational epitope formed by amino acid residues from Glu42 to Thr52 (in green) and additional dispersed amino acids Arg70, Asp72, His76, Ile86, and Lys97 (in green) for Fab binding. The critical residue for antibody binding Glu45 is marked.

identity and similar overall backbone conformation, they share identical molecular surface in terms of shape and charge distribution. This explains the prevalence ofcross-reactive IgE 


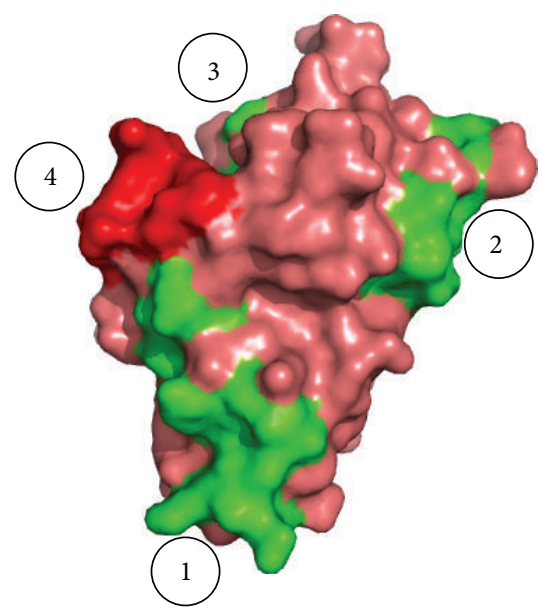

(a)

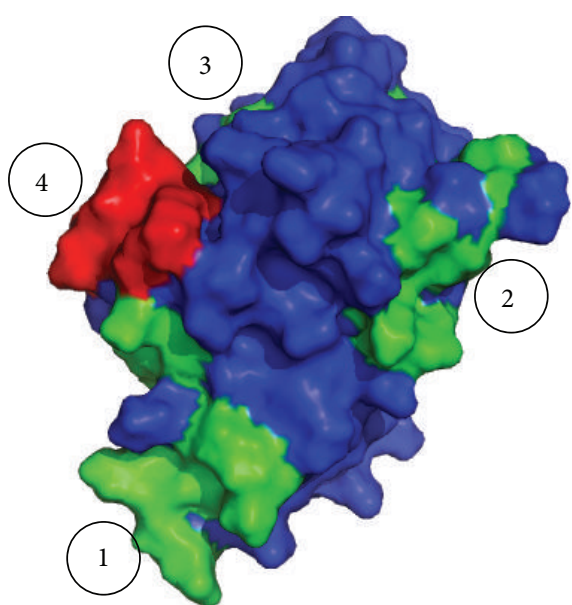

(b)

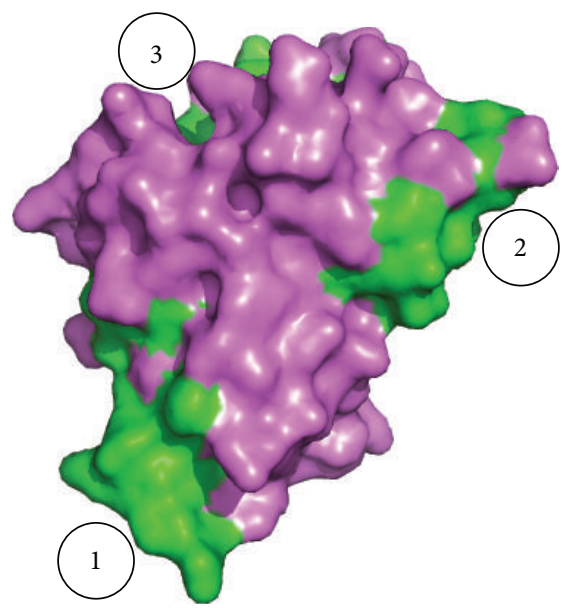

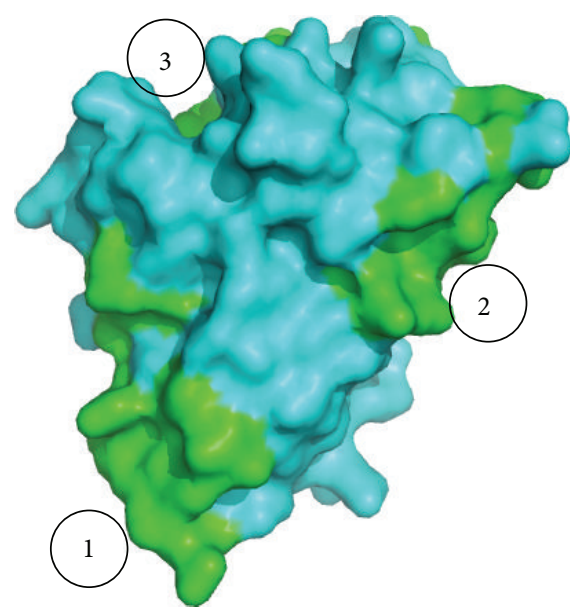

(c)

(d)

Figure 13: The three common surface epitopes (in green) recognized for IgE binding marked from 1 to 3 in (a) Bet v 1, (b) Pru av 1, (c) Api $\mathrm{g}$ 1, and (d) Dau c 1. The conformational epitope required for Fab binding (in red) in Bet v 1 (marked 4) is nearly conserved in Pru av 1 but absent in Api g 1 and Dau c 1 because of the absence of Glu45.

binding epitopes in these proteins [174]. The epitope for antibody binding in Bet $\mathrm{v} 1$ has been found to be nearly conserved in Pru av 1 with Glu45 which may play a similar role in this molecule.

Some structural differences exist between Bet $\mathrm{v} 1$ with Api g 1 and Dau c 1 although these allergens exhibit crossreactivity among themselves $[160,175]$. The latter two share about more than $80 \%$ sequence similarity with each other. Api g 1 lacks the negatively charged Glu45, in contrast to Bet $\mathrm{v} 1$ and Pru av 1 [175]. The epitopes responsible for binding are found to be different from those elucidated by the structure of Bet v 1 in complex with Fab fragment of monoclonal BV16 antibody. Three conserved surface patches responsible for IgE binding are found to be common among Bet v 1, Pru avl, Api g 1, and Dau c 1 (Figure 13). It has also been observed that cross-reactivity between Bet $\mathrm{v} 1$ and Mal d 1 occurs not only at the serologic level but also at the level of allergen specific T helper cells [176]. Eight crossreacting $\mathrm{T}$ cell epitopes have been observed between the two allergens.
3.8. PR-14 Family Allergens. PR-14 proteins are identified as lipid transfer proteins (LTPs) originally named after their ability to transfer phospholipids and other fatty acid groups across cell membranes. They are highly conserved group of small proteins with molecular weights in the range of 9-10 $\mathrm{kDa}$ present in high amounts in higher plants and can also bind to acyl groups. These proteins are present in significant amounts in vascular tissue and in the outer cell layers of plants. They are involved in plant defense against bacterial and fungal pathogeneses as well as under different environmental stresses such as drought, heat, cold, or salt $[177,178]$. There are evidences which suggest that LTPs are also involved in cutin formation, where they act as carriers of acyl monomers and in the process of cell wall extension [179]. They are divided into two types: those specific for certain classes of phospholipids and those that are able to accommodate several lipid classes, called nonspecific LTPs. Allergenic features of nonspecific LTPs (ns-LTPs) were reported in fruits, vegetables, nuts, pollen, and latex [180]. Due to their extreme proteolytic resistance, these allergens 
Peach ITCGQVSS SLAPCIPYVRGGG AVPPA CCNG IRN VNNLARTTPDRQA ACNCLKQLSASVPG 60 Apple ITCGQVTS SLAP CIGYVRSGGAVPPA CCNGIRT INGLARTT ADRQT ACNCLKNLAGSISG 60 Apricot ITCGQVSS SLAP CIGYVRGGGAVPPA CCNGIRN VNNLARTTPDRRTACNCLKQLSGSISG 60 Cherry LTCGQVSS NLAP CI AYVRGGGAVPPA CCNGIRN INNLAKTT ADRQT ACNCLKQLSASVPG 60 Plum ITCGQVSS NLAP CINYVKGGGAVPPA CCNGIRN VNNLARTTADRRA ACNCLKQLSGSIPG 60

Peach VNPNNAA ALPGKCGVSI PYK ISASTNCATVK 91 Apple VNPNNAA GLPGK CGVNVPYKIS TSTN CATVK 91 Apricot VNPNNAA ALPGK CGVNI PYKIS ASTN CATVK 91 Cherry VNANNAA ALPGK CGVNVPYKIS PSTN CATVK 91

Plum VNPNNAA ALPGK CGVNVPYKIS ASTN CATVK 91

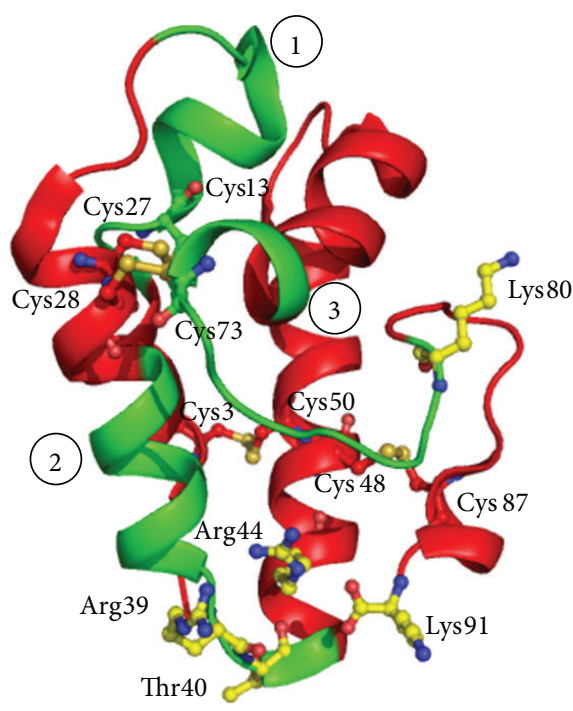

(b)

FIGURE 14: (a) Multiple sequence alignment of allergens of ns-LTPs from four Rosaceaefruits: peach, apple, apricot, and cherry. The identical sequences are highlighted in grey. Eight conserved cysteine residues are highlighted in yellow. The speculated three IgE binding epitopes of Pru p 3 from peach are marked in green. (b) Overall structure of ns-LTP, Pru p 3 showing the three possible IgE epitope binding regions (in green) marked from 1 to 3 . The five charged residues in yellow having a possible role in epitope recognition and the eight cysteine residues forming four disulphide bridges are also marked.

are able to traverse up to the gastrointestinal immune system, allowing sensitization and inducing specific $\operatorname{IgE}$ thereby eliciting severe clinical symptoms [181].

LTPs are the most important allergens of the Rosaceaefruits, such as peach (Pru p 3) [17], apple (Mal d 3) [182], apricot (Pru ar 3) [183], cherry (Pru av 3) [184], and plum (Pru d 3) [185], when no pollinosis is involved. Due to significant sequence identity (more than $81 \%$ ) (Figure 14(a)) shared by ns-LTPs from Rosaceae fruits along with the considerable degree of immunological cross-reactivity, it has been suggested that they have comparable IgE binding epitopes [186]. Patients allergic to PR-14 proteins in fruits tend to have a higher rate of anaphylaxis (36\%) than patients having fruit allergy by PR-10 proteins (18\%).

The structure of the allergen belonging to this family, Pru p 3 from peach, has been extensively studied [187]. The main structural motif is represented by an $\alpha$-helical compact domain, where four helices are connected by short loops (Figure 14(b)). Eight conserved cysteine residues were observed forming four disulfide bridges which makes it highly resistant to harsh temperature and $\mathrm{pH}$ changes. It had been speculated that five positively charged residues, Arg39, Thr40, Arg44, Lys80, and Lys91, are the possible candidates involved in epitope formation. Moreover, using a library of 10-mer synthetic peptides, which screened the whole protein sequence, three potential IgE-binding epitope regions have been identified [188] (Figure 14(b)), which are nearly conserved in other LTPs of Rosaceaefruits (Figure 14(a)).

Recent reports have also indicated that ns-LTPs from species other than Rosaceae, such as nuts, cereals, grapes, oranges, and vegetables, might also be involved for plant food allergies [189]. Severe reactions against hazelnut and chestnut are linked to sensitization to the LTPs, Cor a 8 [190], and Cas s 8 [191], respectively. The major allergens of maize (Zea m 14) [192] and barley (Hor v 14) [193] are also reported to be LTPs and are highly homologous with the peach LTP. LTPs of PR14 family are also reported from pollens including Par $\mathrm{j} 1$ from weeds of Parietaria judaica affecting 50\% of allergic patients in the Mediterranean area [194].

\section{PR-Proteins and Disease Resistant Genetically Modified Crops}

PR proteins are of immense importance as preservative agents in food industry and for producing disease resistant plants by genetic engineering [195]. Various studies have revealed that transgenic plants overexpressing genes of the PR-1, PR-2, PR-3, and PR-5 families mediate host plant resistance to phytopathogenic fungi [196-198]. Coexpression of multiple antifungal protein genes in transgenic plants seems to be more effective than expression of single genes [199]. It is possible that such genetically modified (GM) plants with enhanced expression of PR proteins will also be associated with increased allergenicity and toxicity thus raising a serious question for their commercial acceptability. PR protein, osmotin used for developing transgenic crops, showed cross-reactivity with tomato and apple allergens [134].

Different strategies are adopted to monitor the transformed crops for their allergenicity and various guidelines are defined by the Food and Agriculture Organization (FAO), World Health Organization (WHO), and Codex Alimentarius Commission (Codex) to determine whether a new GM 
crop can be commercialized [200]. The present approach uses a combination of methodologies to evaluate the allergenicity assessment [201]. The allergenicity potential of modified food is primarily speculated on the basis of whether the source of the transformed protein is a plant known to produce allergen and also on the characteristic features of the introduced protein. The homology of the latter to known allergens along with IgE reactivity of the transformed protein with individuals with known allergies to the original source of the novel gene or related allergies is assessed. Moreover, the resistance of the novel protein to pepsin and the immunoreactivity of the novel protein in appropriate animal models are also evaluated [202]. Such step by step approach will provide valuable insights to estimate whether the transformed protein will be allergenic or not.

\section{Conclusions}

PR proteins and their homologues are responsible for the defense against various stresses including pathogen attacks, wounding, use of chemicals, and pollutants. Recent studies have suggested their immense importance in agricultural and food industry with the introduction of transgenic plants. However, many of these protective proteins of the plants have demonstrated allergenicity specially the PR proteins belonging to the families $1,2,3,4,5,8,10$, and 14 . Though there are not much similarities among the different families of PR proteins in terms of their sequence identities or structures, similarity in the amino acid sequences among allergens from diverse plants within the same family results in cross-reactivity. The allergenicity of the PR proteins is also guided by several environmental factors like the use of chemical inducers in agriculture and environmental pollutants. Exploring new PR proteins implicated in allergenicity and a complete understanding of their structures and IgE binding epitopes are necessary for their safe use in plant engineering. The knowledge of the localization of $\mathrm{IgE}$ epitopes on the allergen helps in the identification of cross-reactivity among homologous proteins and may also contribute to the design of effective immunotherapy strategies for certain allergy producing substances like latex, pollen, and so forth along with their respective related allergies.

\section{Conflict of Interests}

The authors declare that there is no conflict of interests regarding the publication of this paper.

\section{Acknowledgments}

The authors acknowledge the financial support from the Indian Council of Medical Research (ICMR), New Delhi. Tej P. Singh thanks the Department of Biotechnology (DBT), for the award of Distinguished Biotechnology Research Professorship. Mau Sinha and Rashmi Prabha Singh thank the Department of Science and Technology (DST), Ministry of Science and Technology, New Delhi, and the Council of
Scientific and Industrial Research (CSIR), respectively, for the award of fellowships. Sanket Kaushik thanks ICMR, New Delhi, and Avinash Singh thanks DBT for their fellowship awards.

\section{References}

[1] S. G. Johansson, "IgE in allergic diseases," Proceedings of the Royal Society of Medicine, vol. 62, no. 9, pp. 975-976, 1969.

[2] D. G. Marsh, L. M. Lichtenstein, and P. S. Norman, "Induction of IgE-mediated immediate hypersensitivity to group I rye grass pollen allergen and allergoids in non-allergic man," Immunology, vol. 22, no. 6, pp. 1013-1028, 1972.

[3] E. A. Taketomi, M. C. Sopelete, P. F. D. S. Moreira, and F. D. A. M. Vieira, "Pollen allergic disease: pollens and its major allergens," Brazilian Journal of Otorhinolaryngology, vol. 72, no. 4, pp. 562-567, 2006.

[4] P. Kennedy, "Acute reaction to apple-eating," British Medical Journal, vol. 2, no. 6150, pp. 1501-1502, 1978.

[5] B. A. Burrall, "Plant-related allergic contact dermatitis," Clinical Reviews in Allergy, vol. 7, no. 4, pp. 417-439, 1989.

[6] P. D. Buisseret, "Seasonal allergic symptoms due to fungal spores," British Medical Journal, vol. 2, no. 6034, pp. 507-508, 1976.

[7] H. L. Spiegelberg and R. A. Simon, "Increase of lymphocytes with $\mathrm{Fc}$ receptors for IgE in patients with allergic rhinitis during the grass pollen season," Journal of Clinical Investigation, vol. 68, no. 4, pp. 845-852, 1981.

[8] M. Mayoral, H. Calderón, R. Cano, and M. Lombardero, "Allergic rhinoconjunctivitis caused by Cannabis sativa pollen," Journal of Investigational Allergology and Clinical Immunology, vol. 18, no. 1, pp. 73-74, 2008.

[9] J. A. Martin, J. A. Compaired, B. de la Hoz et al., "Bronchial asthma induced by chick pea and lentil," Allergy, vol. 47, no. 2, part 2, pp. 185-187, 1992.

[10] R. Valdivieso, J. Subiza, S. Varela-Losada et al., "Bronchial asthma, rhinoconjunctivitis, and contact dermatitis caused by onion," Journal of Allergy and Clinical Immunology, vol. 94, no. 5, pp. 928-930, 1994.

[11] R. K. Chandra, "Food hypersensitivity and allergic diseases," European Journal of Clinical Nutrition, vol. 56, no. 3, pp. S54S56, 2002.

[12] P. Rougé, R. Culerrier, F. Thibau, A. Didier, and A. Barre, "A case of severe anaphylaxis to kidney bean: Phaseolin (vicilin) and PHA (lectin) identified as putative allergens," Allergy, vol. 66, no. 2, pp. 301-302, 2011.

[13] M. T. Gette and J. E. Marks Jr., “Tulip fingers," Archives of Dermatology, vol. 126, no. 2, pp. 203-205, 1990.

[14] S. Goncalo, J. D. Freitas, and I. Sousa, "Contact dermatitis and respiratory symptoms from Narcissus pseudonarcissus," Contact Dermatitis, vol. 16, no. 2, pp. 115-116, 1987.

[15] E. N. C. Mills, J. Jenkins, N. Marigheto, P. S. Belton, A. P. Gunning, and V. J. Morris, "Allergens of the cupin superfamily," Biochemical Society Transactions, vol. 30, part 6, pp. 925-929, 2002.

[16] S. Vrtala, S. Fischer, M. Grote et al., "Molecular, immunological, and structural characterization of $\mathrm{Phl} \mathrm{p} \mathrm{6,} \mathrm{a} \mathrm{major} \mathrm{allergen}$ and P-particle-associated protein from timothy grass (Phleum pratense) pollen," Journal of Immunology, vol. 163, no. 10, pp. 5489-5496, 1999. 
[17] O. A. Duffort, F. Polo, M. Lombardero et al., "Immunoassay to quantify the major peach allergen Pru p 3 in foodstuffs. Differential allergen release and stability under physiological conditions," Journal of Agricultural and Food Chemistry, vol. 50, no. 26, pp. 7738-7741, 2002.

[18] R. D. J. Huby, R. J. Dearman, and I. Kimber, "Why are some proteins allergens?” Toxicological Sciences, vol. 55, no. 2, pp. 235-246, 2000.

[19] S. B. Lehrer, W. E. Horner, and G. Reese, "Why are some proteins allergenic? Implications for biotechnology," Critical Reviews in Food Science and Nutrition, vol. 36, no. 6, pp. 553-564, 1996.

[20] L. C. van Loon, "Pathogenesis-related proteins," Plant Molecular Biology, vol. 4, no. 2-3, pp. 111-116, 1985.

[21] J. Rigden and R. Coutts, "Pathogenesis-related proteins in plants," Trends in Genetics, vol. 4, no. 4, pp. 87-89, 1988.

[22] C. J. Lamb, M. A. Lawton, M. Dron, and R. A. Dixon, "Signals and transduction mechanisms for activation of plant defenses against microbial attack," Cell, vol. 56, no. 2, pp. 215-224, 1989.

[23] T. P. Delaney, S. Uknes, B. Vernooij et al., "A central role of salicylic acid in plant disease resistance," Science, vol. 266, no. 5188, pp. 1247-1250, 1994.

[24] X. Y. Xu Yi, L. Chang Pi Fang, L. D. Liu Dong et al., "Plant defense genes are synergistically induced by ethylene and methyl jasmonate," Plant Cell, vol. 6, no. 8, pp. 1077-1085, 1994.

[25] H. J. Linthorst, L. C. van Loon, C. M. van Rossum et al., "Analysis of acidic and basic chitinases from tobacco and petunia and their constitutive expression in transgenic tobacco," Molecular Plant-Microbe Interactions, vol. 3, no. 4, pp. 252-258, 1990.

[26] T. Lotan, N. Ori, and R. Fluhr, "Pathogenesis-related proteins are developmentally regulated in tobacco flowers," The Plant Cell, vol. 1, no. 9, pp. 881-887, 1989.

[27] L. C. van Loon, W. S. Pierpoint, T. Boller, and V. Conejero, "Recommendations for naming plant pathogenesis-related proteins," Plant Molecular Biology Reporter, vol. 12, no. 3, pp. 245264, 1994.

[28] L. C. van Loon and A. van Kammen, "Polyacrylamide disc electrophoresis of the soluble leaf proteins from Nicotiana tabacum var. "Samsun" and "Samsun NN". II: changes in protein constitution after infection with tobacco mosaic virus," Virology, vol. 40, no. 2, pp. 199-211, 1970.

[29] L. C. van Loon and E. A. van Strien, "The families of pathogenesis-related proteins, their activities, and comparative analysis of PR-1 type proteins," Physiological and Molecular Plant Pathology, vol. 55, no. 2, pp. 85-97, 1999.

[30] A. S. Buchel and H. J. M. Linthorst, "PR-1: a group of plant proteins induced upon pathogen infection," in PathogenesisRelated Proteins in Plants, S. K. Datta and S. Muthukrishnan, Eds., pp. 21-47, CRC Press LLC, Boca Raton, Fla, USA, 1999.

[31] M. Ohshima, H. Itoh, M. Matsuoka, T. Murakami, and Y. Ohashi, "Analysis of stress-induced or salicylic acid-induced expression of the pathogenesis-related la protein gene in transgenic tobacco," Plant Cell, vol. 2, no. 2, pp. 95-106, 1990.

[32] N. Yalpani, P. Silverman, T. M. A. Wilson, D. A. Kleier, and I. Raskin, "Salicylic acid is a systemic signal and an inducer of pathogenesis-related proteins in virus-infected tobacco," Plant Cell, vol. 3, no. 8, pp. 809-818, 1991.

[33] S. Chamnongpol, H. Willekens, W. Moeder et al., "Defense activation and enhanced pathogen tolerance induced by $\mathrm{H}_{2} \mathrm{O}_{2}$ in transgenic tobacco," Proceedings of the National Academy of Sciences of the United States of America, vol. 95, no. 10, pp. 58185823, 1998.
[34] S. Kitajima and F. Sato, "Plant pathogenesis-related proteins: molecular mechanisms of gene expression and protein function," Journal of Biochemistry, vol. 125, no. 1, pp. 1-8, 1999.

[35] S. K. Datta and S. Muthukrishnan, Pathogenesis-Related Proteins in Plants, CRC Press, Boca Raton, Fla, USA, 1999.

[36] L. C. van Loon, M. Rep, and C. M. J. Pieterse, "Significance of inducible defense-related proteins in infected plants," Annual Review of Phytopathology, vol. 44, pp. 135-162, 2006.

[37] J. Hejgaard, S. Jacobsen, and I. Svendsen, "Two antifungal thaumatin-like proteins from barley grain," FEBS Letters, vol. 291, no. 1, pp. 127-131, 1991.

[38] C. Caruso, C. Caporale, G. Chilosi et al., "Structural and antifungal properties of a pathogenesis-related protein from wheat kernel," Journal of Protein Chemistry, vol. 15, no. 1, pp. 35-44, 1996.

[39] J. R. Cutt, M. H. Harpster, D. C. Dixon, J. P. Carr, P. Dunsmuir, and D. F. Klessig, "Disease response to tobacco mosaic virus in transgenic tobacco plants that constitutively express the pathogenesis-related PRlb gene," Virology, vol. 173, no. 1, pp. 8997, 1989.

[40] A. Edreva, "Pathogenesis-related proteins: research progress in the last 15 years," General and Applied Plant Physiology, vol. 31, no. 1-2, pp. 105-124, 2005.

[41] E. Kombrink, M. Schroder, and K. Hahlbrock, "Several "pathogenesis-related" proteins in potato are 1,3- $\beta$-glucanases and chitinases," Proceedings of the National Academy of Sciences of the United States of America, vol. 85, no. 3, pp. 782-786, 1988.

[42] T. Heitz, S. Segond, S. Kauffmann et al., "Molecular characterization of a novel tobacco pathogenesis-related (PR) protein: a new plant chitinase/lysozyme," Molecular and General Genetics, vol. 245, no. 2, pp. 246-254, 1994.

[43] F. T. Lay and M. A. Anderson, "Defensins-components of the innate immune system in plants," Current Protein and Peptide Science, vol. 6, no. 1, pp. 85-101, 2005.

[44] M. C. Regente, A. M. Giudici, J. Villalaín, and L. de la Canal, "The cytotoxic properties of a plant lipid transfer protein involve membrane permeabilization of target cells," Letters in Applied Microbiology, vol. 40, no. 3, pp. 183-189, 2005.

[45] T. Heitz, P. Geoffroy, B. Fritig, and M. Legrand, "Two apoplastic $\alpha$-amylases are induced in tobacco by virus infection," Plant Physiology, vol. 97, no. 2, pp. 651-655, 1991.

[46] G. De Lorenzo, R. D'Ovidio, and F. Cervone, "The role of polygalacturonase-inhibiting proteins (PGIPS) in defense against pathogenic fungi," Annual Review of Phytopathology, vol. 39, pp. 313-335, 2001.

[47] S. Deepak, S. Shailasree, R. K. Kini, B. Hause, S. H. Shetty, and A. Mithöfer, "Role of hydroxyproline-rich glycoproteins in resistance of pearl millet against downy mildew pathogen Sclerospora graminicola," Planta, vol. 226, no. 2, pp. 323-333, 2007.

[48] A. Akram, M. Ongena, F. Duby, J. Dommes, and P. Thonart, "Systemic resistance and lipoxygenase-related defence response induced in tomato by Pseudomonas putida strain BTP1," BMC Plant Biology, vol. 8, article 113, 2008.

[49] S. Cândido Ede, M. F. Pinto, P. B. Pelegrini et al., "Plant storage proteins with antimicrobial activity: novel insights into plant defense mechanisms," FASEB Journal, vol. 25, no. 10, pp. 32903305, 2011.

[50] W. J. Peumans and E. J. van Damme, "Lectins as plant defense proteins," Plant Physiology, vol. 109, no. 2, pp. 347-352, 1995. 
[51] W. J. Peumans, Q. Hao, and E. J. M. van Damme, "Ribosomeinactivating proteins from plants: more than RNA N-glycosidases?” FASEB Journal, vol. 15, no. 9, pp. 1493-1506, 2001.

[52] W. F. Broekaert, F. R. G. Terras, and B. P. A. Cammue, "Induced and preformed antimicrobial proteins," in Mechanisms of Resistance to Plant Diseases, A. J. Slusarenko, R. S. Fraser, and L. C. van Loon, Eds., pp. 371-477, Kluwer Academic Publishers, Dordrecht, The Netherlands, 2000.

[53] K. Hoffmann-Sommergruber, "Plant allergens and pathogenesis-related proteins: what do they have in common?" International Archives of Allergy and Immunology, vol. 122, no. 3, pp. 155-166, 2000.

[54] C. Ebner, K. Hoffmann-Sommergruber, and H. Breiteneder, "Plant food allergens homologous to pathogenesis-related proteins," Allergy, Supplement, vol. 56, no. 67, pp. 43-44, 2001.

[55] T. Midoro-Horiuti, E. G. Brooks, and R. M. Goldblum, "Pathogenesis-related proteins of plants as allergens," Annals of Allergy, Asthma and Immunology, vol. 87, no. 4, pp. 261-271, 2001.

[56] K. Hoffmann-Sommergruber, "Pathogenesis-related (PR)proteins identified as allergens," Biochemical Society Transactions, vol. 30, no. 6, pp. 930-935, 2002.

[57] L. Halmepuro, K. Vuontela, K. Kalimo, and F. Bjorksten, “Crossreactivity of IgE antibodies with allergens in birch pollen, fruits and vegetables," International Archives of Allergy and Applied Immunology, vol. 74, no. 3, pp. 235-240, 1984.

[58] C. Blanco, T. Carrillo, R. Castillo, J. Quiralte, and M. Cuevas, "Latex allergy: clinical features and cross-reactivity with fruits," Annals of Allergy, vol. 73, no. 4, pp. 309-314, 1994.

[59] R. Asero, "Lipid transfer protein cross-reactivity assessed in vivo and in vitro in the office: pros and cons," Journal of Investigational Allergology and Clinical Immunology, vol. 21, no. 2, pp. 129-136, 2011.

[60] R. E. Rossi, G. Monasterolo, D. Operti, and M. Corsi, "Evaluation of recombinant allergens Bet v 1 and Bet v 2 (profilin) by Pharmacia CAP System in patients with pollen-related allergy to birch and apple," Allergy, vol. 51, no. 12, pp. 940-945, 1996.

[61] S. Wagner and H. Breiteneder, "The latex-fruit syndrome," Biochemical Society Transactions, vol. 30, part 6, pp. 935-940, 2002.

[62] A. Leitner, E. Jensen-Jarolim, R. Grimm et al., "Allergens in pepper and paprika: immunologic investigation of the celerybirch-mugwort-spice syndrome," Allergy, vol. 53, no. 1, pp. 3641, 1998.

[63] T. Midoro-Horiuti, R. M. Goldblum, A. Kurosky, T. G. Wood, and E. G. Brooks, "Variable expression of pathogenesis-related protein allergen in mountain cedar (Juniperus ashei) pollen," Journal of Immunology, vol. 164, no. 4, pp. 2188-2192, 2000.

[64] B. J. Cornelissen, R. A. Hooft van Huijsduijnen, L. C. van Loon, and J. F. Bol, "Molecular characterization of messenger RNAs for "pathogenesis related" proteins $\mathrm{la}, \mathrm{lb}$ and $\mathrm{lc}$, induced by TMV infection of tobacco," The EMBO Journal, vol. 5, no. 1, pp. 37-40, 1986.

[65] M. H. A. J. Joosten, C. J. B. Bergmans, E. J. S. Meulenhoff, B. J. C. Cornelissen, and P. J. G. M. De Wit, "Purification and serological characterization of three basic 15-kilodalton pathogenesis-related proteins from tomato," Plant Physiology, vol. 94 , no. 2, pp. 585-591, 1990.

[66] T. Niderman, I. Genetet, T. Bruyere et al., "Pathogenesis-related PR-1 proteins are antifungal. Isolation and characterization of three 14-kilodalton proteins of tomato and of a basic PR1 of tobacco with inhibitory activity against Phytophthora infestans," Plant Physiology, vol. 108, no. 1, pp. 17-27, 1995.
[67] J. W. Gillikin, W. Burkhart, and J. S. Graham, "Complete amino acid sequence of a polypeptide from Zea mays similar to the pathogenesis-related-1 family," Plant Physiology, vol. 96, no. 4, pp. 1372-1375, 1991.

[68] Q. Liu and Q. Xue, "Computational identification of novel PR1-type genes in Oryza sativa," Journal of Genetics, vol. 85, no. 3, pp. 193-198, 2006.

[69] T. Asensio, J. F. Crespo, R. Sanchez-Monge et al., "Novel plant pathogenesis-related protein family involved in food allergy," Journal of Allergy and Clinical Immunology, vol. 114, no. 4, pp. 896-899, 2004.

[70] P. B. Hoj and G. B. Fincher, "Molecular evolution of plant betaglucan endohydrolases," Plant Journal, vol. 7, no. 3, pp. 367-379, 1995.

[71] R. G. Fulcher, M. E. Mc Cully, G. Setterfield, and J. Sutherland, " $\beta$-1,3-glucans may be associated with cell plate formation during cytokinesis," Canadian Journal Botany, vol. 54, pp. 459542, 1976.

[72] P. A. Bucciaglia and A. G. Smith, "Cloning and characterization of Tag 1, a tobacco anther beta-1,3-glucanase expressed during tetrad dissolution," Plant Molecular Biology, vol. 24, no. 6, pp. 903-914, 1994.

[73] P. J. Meikle, I. Bonig, N. J. Hoogenraad, A. E. Clarke, and B. A. Stone, "The location of $(1 \rightarrow 3)$ - $\beta$-glucans in the walls of pollen tubes of Nicotiana alata using a $(1 \rightarrow 3)-\beta$-glucan-specific monoclonal antibody," Planta, vol. 185, no. 1, pp. 1-8, 1991.

[74] S. Helleboid, G. Bauw, L. Belingheri, J. Vasseur, and J. L. Fulbert, "Extracellular $\beta$-1,3-glucanases are induced during early somatic embryogenesis in Cichorium," Planta, vol. 205, no. 1, pp. 56-63, 1998.

[75] G. Leubner-Metzger, C. Frundt, R. Vogeli-Lange, and F. Meins Jnr, "Class I beta-1,3-glucanases in the endosperm of tobacco during germination," Plant Physiology, vol. 109, no. 3, pp. 751759, 1995.

[76] G. B. Fincher and B. A. Stone, "Physiology and biochemistry of germination in barley," in Barley: Chemistry and Technology, A. W. MacGregor and R. S. Bhatty, Eds., pp. 247-295, St. Paul, American Association of Cereal Chemists, 1993.

[77] M. Thalmair, G. Bauw, S. Thiel, T. Döhring, C. Langebartels, and H. Sandermann Jr., "Ozone and ultraviolet B effects on the defense-related proteins $\beta$-1,3-glucanase and chitinase in Tobacco," Journal of Plant Physiology, vol. 148, no. 1-2, pp. 222228, 1996.

[78] D. K. Hincha, F. Meins Jr., and J. M. Schmitt, “ $\beta$-1,3-glucanase is cryoprotective in vitro and is accumulated in leaves during cold acclimation," Plant Physiology, vol.114, no. 3, pp. 1077-1083, 1997.

[79] F. T. Brederode, H. J. M. Linthorst, and J. F. Bol, "Differential induction of acquired resistance and $\mathrm{PR}$ gene expression in tobacco by virus infection, ethephon treatment, UV light and wounding," Plant Molecular Biology, vol. 17, no. 6, pp. 1117-1125, 1991.

[80] G. Payne, E. Ward, T. Gaffney et al., "Evidence for a third structural class of $\beta$-1,3-glucanase in tobacco," Plant Molecular Biology, vol. 15, no. 6, pp. 797-808, 1990.

[81] M. V. Bulcke, G. Bauw, C. Castresana, M. van Montagu, and J. Vandekerckhove, "Characterization of vacuolar and extracellular $\beta$-(1,3)-glucanases of tobacco: evidence for a strictly compartmentalized plant defense system," Proceedings of the National Academy of Sciences of the United States of America, vol. 86, no. 8, pp. 2673-2677, 1989. 
[82] C. R. Simmons, "The physiology and molecular biology of plant 1,3- $\beta$-D-glucanases and 1,3;1,4- $\beta$-D-glucanases," Critical Reviews in Plant Sciences, vol. 13, no. 4, pp. 325-387, 1994.

[83] L. Sticher, U. Hinz, A. D. Meyer, and F. Meins Jr., "Intracellular transport and processing of a tobacco vacuolar $\beta$-1,3-glucanase," Planta, vol. 188, no. 4, pp. 559-565, 1992.

[84] C. A. Hirshman, "Latex anaphylaxis," Anesthesiology, vol. 77, no. 2, pp. 223-225, 1992.

[85] R. De Zotti, F. Larese, and A. Fiorito, "Asthma and contact urticaria from latex gloves in a hospital nurse," British Journal of Industrial Medicine, vol. 49, no. 8, pp. 596-598, 1992.

[86] M. L. Chye and K. Y. Cheung, " $\beta-1,3$-glucanase is highlyexpressed in laticifers of Hevea brasiliensis," Plant Molecular Biology, vol. 29, no. 2, pp. 397-402, 1995.

[87] E. Sunderasan, S. Hamzah, S. Hamid et al., "Latex B-serum $\beta$ 1,3-glucanase (Hev b 2) and a component of the microhelix (Hev b 4) are major latex allergens," Journal of Natural Rubber Research, vol. 10, pp. 82-99, 1996.

[88] V. P. Kurup, H. Y. Yeang, G. L. Sussman et al., "Detection of immunoglobulin antibodies in the sera of patients using purified latex allergens," Clinical and Experimental Allergy, vol. 30, no. 3, pp. 359-369, 2000.

[89] V. P. Kurup, G. L. Sussman, H. Y. Yeang et al., "Specific IgE response to purified and recombinant allergens in latex allergy," Clinical and Molecular Allergy, vol. 3, article 11, 2005.

[90] A. Barre, R. Culerrier, C. Granier et al., "Mapping of IgEbinding epitopes on the major latex allergen Hev b 2 and the cross-reacting 1,3- $\beta$-glucanase fruit allergens as a molecular basis for the latex-fruit syndrome," Molecular Immunology, vol. 46, no. 8-9, pp. 1595-1604, 2009.

[91] C. Blanco, T. Carrillo, R. Castillo, J. Quiralte, and M. Cuevas, "Avocado hypersensitivity," Allergy, vol. 49, no. 6, pp. 454-459, 1994.

[92] R. Brehler, U. Theissen, C. Mohr, and T. Luger, "Latex-fruit syndrome':frequency of cross-reacting IgE antibodies," Allergy, vol. 52, no. 4, pp. 404-410, 1997.

[93] S. Wagner, C. Radauer, C. Hafner et al., "Characterization of cross-reactive bell pepper allergens involved in the latex-fruit syndrome," Clinical and Experimental Allergy, vol. 34, no. 11, pp. 1739-1746, 2004.

[94] S. K. Clendennen and G. D. May, "Differential gene expression in ripening banana fruit," Plant Physiology, vol. 115, no. 2, pp. 463-469, 1997.

[95] S. Huecas, M. Villalba, and R. Rodríguez, "Ole e 9, a major olive pollen allergen is a 1,3- $\beta$-glucanase: isolation, characterization, amino acid sequence, and tissue specificity," Journal of Biological Chemistry, vol. 276, no. 30, pp. 27959-27966, 2001.

[96] M. Á. Treviño, O. Palomares, I. Castrillo et al., "Solution structure of the C-terminal domain of Ole e 9, a major allergen of olive pollen," Protein Science, vol. 17, no. 2, pp. 371-376, 2008.

[97] P. Jollès and R. A. A. Muzzarelli, Chitin and Chitinases, Birkhauser, Basel, Switzerland, 1999.

[98] J. M. Neuhaus, L. Sticher, F. Meins Jr., and T. Boller, "A short Cterminal sequence is necessary and sufficient for the targeting of chitinases to the plant vacuole," Proceedings of the National Academy of Sciences of the United States of America, vol. 88, no. 22, pp. 10362-10366, 1991.

[99] L. S. Graham and M. B. Sticklen, "Plant chitinases," Canadian Journal of Botany, vol. 72, no. 8, pp. 1057-1083, 1994.

[100] A. Diaz-Perales, C. Collada, C. Blanco et al., "Class I chitinases with hevein-like domain, but not class II enzymes, are relevant chestnut and avocado allergens," Journal of Allergy and Clinical Immunology, vol. 102, no. 1, pp. 127-133, 1998.

[101] S. Sowka, L. S. Hsieh, M. Krebitz et al., "Identification and cloning of Prs a 1, a 32-kDa endochitinase and major allergen of avocado, and its expression in the yeast Pichia pastoris," Journal of Biological Chemistry, vol. 273, no. 43, pp. 28091-28097, 1998.

[102] A. Posch, C. H. Wheeler, Z. Chen et al., "Class I endochitinase containing a hevein domain is the causative allergen in latexassociated avocado allergy," Clinical and Experimental Allergy, vol. 29, no. 5, pp. 667-672, 1999.

[103] R. Sanchez-Monge, C. Blanco, A. Dïaz-Perales et al., "Isolation and characterization of major banana allergens: identification as fruit class I chitinases," Clinical and Experimental Allergy, vol. 29, no. 5, pp. 673-680, 1999.

[104] A. S. Ponstein, S. A. Bres-Vloemans, M. B. Sela-Buurlage, P. J. M. van den Elzen, L. S. Melchers, and B. J. C. Cornelissen, "A novel pathogen- and wound-inducible tobacco (Nicotiana tabacum) protein with antifungal activity," Plant Physiology, vol. 104, no. 1, pp. 109-118, 1994.

[105] S. Ludvigsen and F. M. Poulsen, "Three-dimensional structure in solution of barwin, a protein from barley seed," Biochemistry, vol. 31, no. 37, pp. 8783-8789, 1992.

[106] H. Alenius, N. Kalkkinen, M. Lukka et al., "Prohevein from the rubber tree (Hevea brasiliensis) is a major latex allergen," Clinical and Experimental Allergy, vol. 25, no. 7, pp. 659-665, 1995.

[107] M. Raulf-Heimsoth, P. Rozynek, T. Brüning, and H. P. Rihs, "Characterization of B- and T-cell responses and HLA-DR4 binding motifs of the latex allergen Hev b 6.01 (prohevein) and its post-transcriptionally formed proteins $\mathrm{Hev}$ b 6.02 and $\mathrm{Hev} b$ 6.03," Allergy, vol. 59, no. 7, pp. 724-733, 2004.

[108] P. Karisola, A. Kotovuori, S. Poikonen et al., "Isolated heveinlike domains, but not 31-kd endochitinases, are responsible for IgE-mediated in vitro and in vivo reactions in latex-fruit syndrome," Journal of Allergy and Clinical Immunology, vol. 115, no. 3, pp. 598-605, 2005.

[109] Z. Chen, A. Posch, R. Cremer, M. Raulf-Heimsoth, and X. Baur, "Identification of hevein (Hev b 6.02) inHevea latex as a major cross-reacting allergen with avocado fruit in patients with latex allergy," Journal of Allergy and Clinical Immunology, vol. 102, no. 3, pp. 476-481, 1998.

[110] C. A. Reyes-López, A. Hernández-Santoyo, M. Pedraza-Escalona, G. Mendoza, A. Hernández-Arana, and A. RodríguezRomero, "Insights into a conformational epitope of Hev b 6.02 (hevein)," Biochemical and Biophysical Research Communications, vol. 314, no. 1, pp. 123-130, 2004.

[111] A. C. Drew, N. P. Eusebius, L. Kenins et al., "Hypoallergenic variants of the major latex allergen Hev b 6.01 retaining human T lymphocyte reactivity," Journal of Immunology, vol. 173, no. 9, pp. 5872-5879, 2004.

[112] H. J. Linthorst, N. Danhash, F. T. Brederode, J. A. van Kan, P. J. De Wit, and J. F. Bol, "Tobacco and tomato PR proteins homologous to win and pro-hevein lack the "hevein" domain," Molecular Plant-Microbe Interactions, vol. 4, no. 6, pp. 586-592, 1991.

[113] A. R. Hänninen, J. H. Mikkola, N. Kalkkinen et al., "Increased allergen production in turnip (Brassica rapa) by treatments activating defense mechanisms," Journal of Allergy and Clinical Immunology, vol. 104, no. 1, pp. 194-201, 1999.

[114] W. F. Daniell, "On the Synsepalum dulcificum, Decand, or miraculous berry of Western Africa," Pharmaceutical Journal, vol. 11, pp. 445-448, 1852. 
[115] B. J. C. Cornelissen, R. A. M. Hooft van Huijsduijen, and J. F. Bol, "A tobacco mosaic virus-induced tobacco protein is homologous to the sweet-tasting protein thaumatin," Nature, vol. 321, no. 6069, pp. 531-532, 1986.

[116] N. K. Singh, C. A. Bracker, P. M. Hasegawa et al., "Characterization of osmotin: a thaumatin-like protein associated with osmotic adaptation in plant cells," Plant Physiology, vol. 85, no. 2, pp. 529-536, 1987.

[117] R. Pressey, "Two isoforms of NP24: a thaumatin-like protein in tomato fruit," Phytochemistry, vol. 44, no. 7, pp. 1241-1245, 1997.

[118] N. E. Cheong, Y. O. Choi, W. Y. Kim, S. C. Kim, M. J. Cho, and S. Y. Lee, "Purification of an antifungal PR-5 protein from flower buds of Brassica campestris and cloning of its gene," Physiologia Plantarum, vol. 101, no. 3, pp. 583-590, 1997.

[119] B. R. Fils-Lycaon, P. A. Wiersma, K. C. Eastwell, and P. Sautiere, "A cherry protein and its gene, abundantly expressed in ripening fruit, have been identified as thaumatin-like," Plant Physiology, vol. 111, no. 1, pp. 269-273, 1996.

[120] W. K. Roberts and C. P. Selitrennikoff, "Zeamatin, an antifungal protein from maize with membrane-permeabilizing activity," Journal of General Microbiology, vol. 136, no. 9, pp. 1771-1778, 1990.

[121] A. J. Vigers, W. K. Roberts, and C. P. Selitrennikoff, "A new family of plant antifungal proteins," Molecular Plant-Microbe Interactions, vol. 4, no. 4, pp. 315-323, 1991.

[122] N. Futamura, Y. Mukai, M. Sakaguchi et al., "Isolation and characterization of cDNAs that encode homologs of a pathogenesisrelated protein allergen from Cryptomeria japonica," Bioscience, Biotechnology and Biochemistry, vol. 66, no. 11, pp. 2495-2500, 2002.

[123] I. Cortegano, E. Civantos, E. Aceituno et al., "Cloning and expression of a major allergen from Cupressus arizonica pollen, Cup a 3, a PR-5 protein expressed under polluted environment," Allergy, vol. 59, no. 5, pp. 485-490, 2004.

[124] T. Midoro-Horiuti, R. M. Goldblum, and E. G. Brooks, "Identification of mutations in the genes for the pollen allergens of eastern red cedar (Juniperus virginiana)," Clinical and Experimental Allergy, vol. 31, no. 5, pp. 771-778, 2001.

[125] H. C. Fuchs, B. Bohle, Y. Dall'Antonia et al., "Natural and recombinant molecules of the cherry allergen Pru av 2 show diverse structural and B cell characteristics but similar $\mathrm{T}$ cell reactivity," Clinical and Experimental Allergy, vol. 36, no. 3, pp. 359-368, 2006.

[126] M. D. Anliker, S. Borelli, and B. Wüthrich, "Occupational protein contact dermatitis from spices in a butcher: a new presentation of the mugwort-spice syndrome," Contact Dermatitis, vol. 46, no. 2, pp. 72-74, 2002.

[127] M. Krebitz, B. Wagner, F. Ferreira et al., "Plant-based heterologous expression of Mal d 2, a thaumatin-like protein and allergen of apple (Malus domestica), and its characterization as an antifungal protein," Journal of Molecular Biology, vol. 329, no. 4, pp. 721-730, 2003.

[128] A. Palacin, J. Rodriguez, C. Blanco et al., "Immunoglobulin e recognition patterns to purified kiwifruit (Actinidinia deliciosa) allergens in patients sensitized to kiwi with different clinical symptoms," Clinical and Experimental Allergy, vol. 38, no. 7, pp. 1220-1228, 2008.

[129] A. Palacín, L. Tordesillas, P. Gamboa et al., "Characterization of peach thaumatin-like proteins and their identification as major peach allergens," Clinical and Experimental Allergy, vol. 40, no. 9, pp. 1422-1430, 2010.
[130] G. Salcedo, S. Quirce, and A. Diaz-Perales, "Wheat allergens associated with Baker's asthma," Journal of Investigational Allergology and Clinical Immunology, vol. 21, no. 2, pp. 81-92, 2011.

[131] E. A. Pastorello, L. Farioli, V. Pravettoni et al., "Identification of grape and wine allergens as an endochitinase 4, a lipidtransfer protein, and a thaumatin," Journal of Allergy and Clinical Immunology, vol. 111, no. 2, pp. 350-359, 2003.

[132] P. Leone, L. Menu-Bouaouiche, W. J. Peumans et al., "Resolution of the structure of the allergenic and antifungal banana fruit thaumatin-like protein at 1.7-Å," Biochimie, vol. 88, no. 1, pp. 4552, 2006.

[133] S. Barthakur, V. Babu, and K. C. Bansal, "Over-expression of osmotin induces proline accumulation and confers tolerance to osmotic stress in transgenic tobacco," Journal of Plant Biochemistry and Biotechnology, vol. 10, no. 1, pp. 31-37, 2001.

[134] P. Sharma, A. K. Singh, B. P. Singh, S. N. Gaur, and N. Arora, "Allergenicity assessment of osmotin, a pathogenesis-related protein, used for transgenic crops," Journal of Agricultural and Food Chemistry, vol. 59, no. 18, pp. 9990-9995, 2011.

[135] P. Sharma, S. N. Gaur, and N. Arora, "In silico identification of IgE-binding epitopes of osmotin protein," PLoS ONE, vol. 8, no. 1, Article ID e54755, 2013.

[136] P. Bernasconi, R. Locher, P. E. Pilet, J. Jollès, and P. Jollès, "Purification and N-terminal amino-acid sequence of a basic lysozyme from Parthenocissus quinquifolia cultured in vitro," Biochimica et Biophysica Acta, vol. 915, no. 2, pp. 254-260, 1987.

[137] A. C. Terwisscha van Scheltinga, M. Hennig, and B. W. Dijkstra, "The $1.8 \AA$ resolution structure of hevamine, a plant chitinase/lysozyme, and analysis of the conserved sequence and structure motifs of glycosyl hydrolase family 18," Journal of Molecular Biology, vol. 262, no. 2, pp. 243-257, 1996.

[138] A. Perrakis, I. Tews, Z. Dauter et al., "Crystal structure of a bacterial chitinase at $2.3 \AA$ resolution," Structure, vol. 2, no. 12, pp. 1169-1180, 1994.

[139] M. F. Lee, Y. H. Chen, H. C. Lin, H. L. Wang, G. Y. Hwang, and C. H. Wu, "Identification of hevamine and Hev b 1 as major latex allergens in Taiwan," International Archives of Allergy and Immunology, vol. 139, no. 1, pp. 38-44, 2005.

[140] M. F. Lee, N. M. Wang, J. L. Han, S. J. Lin, J. J. Tsai, and Y. H. Chen, "Estimating allergenicity of latex gloves using Hev b 1 and hevamine," Journal of Investigational Allergology and Clinical Immunology, vol. 20, no. 6, pp. 499-505, 2010.

[141] M. F. Lee, G. Y. Hwang, Y. H. Chen, H. C. Lin, and C. H. $\mathrm{Wu}$, "Molecular cloning of Indian jujube (Zizyphus mauritiana) allergen Ziz $\mathrm{m} 1$ with sequence similarity to plant class III chitinases," Molecular Immunology, vol. 43, no. 8, pp. 1144-1151, 2006.

[142] M. F. Lee, J. J. Tsai, G. Y. Hwang, S. J. Lin, and Y. H. Chen, "Identification of immunoglobulin E (IgE)-binding epitopes and recombinant IgE reactivities of a latex cross-reacting Indian jujube Ziz m 1 allergen," Clinical and Experimental Immunology, vol. 152, no. 3, pp. 464-471, 2008.

[143] M. F. Lee, S. J. Lin, N. M. Wang, H. J. Wu, and Y. H. Chen, "Plant chitinase III Ziz m 1 stimulates multiple cytokines, most predominantly interleukin-13, from peripheral blood mononuclear cells of latex-fruit allergic patients," Annals of Allergy, Asthma and Immunology, vol. 108, no. 2, pp. 113-116, 2012.

[144] N. Manavski, U. Peters, R. Brettschneider, M. Oldenburg, X. Baur, and C. Bittner, "Cof a 1: identification, expression and immunoreactivity of the first coffee allergen," International Archives of Allergy and Immunology, vol. 159, no. 3, pp. 235-242, 2012. 
[145] S. A. J. Warner, R. Scott, and J. Draper, "Characterisation of a wound-induced transcript from the monocot asparagus that shares similarity with a class of intracellular pathogenesisrelated (PR) proteins," Plant Molecular Biology, vol. 19, no. 4, pp. 555-561, 1992.

[146] M. H. Walter, J. W. Liu, C. Grand, C. J. Lamb, and D. Hess, "Bean pathogenesis-related (PR) proteins deduced from elicitor-induced transcripts are members of a ubiquitous new class of conserved PR proteins including pollen allergens," Molecular and General Genetics, vol. 222, no. 2-3, pp. 353-360, 1990.

[147] C. Breda, C. Sallaud, J. El-Turk et al., "Defense reaction in Medicago sativa: a gene encoding a class $10 \mathrm{PR}$ protein is expressed in vascular bundles," Molecular Plant-Microbe Interactions, vol. 9, no. 8, pp. 713-719, 1996.

[148] I. E. Somssich, E. Schmelzer, P. Kawalleck, and K. Hahlbrock, "Gene structure and in situ transcript localization of pathogenesis-related protein 1 in parsley," MGG Molecular \& General Genetics, vol. 213, no. 1, pp. 93-98, 1988.

[149] A. K. M. Ekramoddoullah, "Physiology and molecular biology of a family of pathogenesis-related PR-10 proteins in conifers," Journal of Crop Improvement, vol. 10, no. 1-2, pp. 261-280, 2004.

[150] H. Fernandes, K. Michalska, M. Sikorski, and M. Jaskolski, "Structural and functional aspects of PR-10 proteins," FEBS Journal, vol. 280, no. 5, pp. 1169-1199, 2013.

[151] N. Tokuriki and D. S. Tawfik, "Protein dynamism and evolvability," Science, vol. 324, no. 5924, pp. 203-207, 2009.

[152] J. E. Mogensen, R. Wimmer, J. N. Larsen, M. D. Spangfort, and D. E. Otzen, "The major birch allergen, Bet v 1 , shows affinity for a broad spectrum of physiological ligands," Journal of Biological Chemistry, vol. 277, no. 26, pp. 23684-23692, 2002.

[153] H. Breiteneder, K. Pettenburger, A. Bito et al., "The gene coding for the major birch pollen allergen BetvI, is highly homologous to a pea disease resistance response gene," EMBO Journal, vol. 8, no. 7, pp. 1935-1938, 1989.

[154] M. F. Schenk, J. H. Cordewener, A. H. America, W. P. Van'T Westende, M. J. Smulders, and L. J. Gilissen, "Characterization of PR-10 genes from eight betula species and detection of Bet v 1 isoforms in birch pollen," BMC Plant Biology, vol. 9, article 24, 2009.

[155] H. Breiteneder, K. Hoffmann-Sommergruber, G. O'Riordain et al., "Molecular characterization of Api g 1, the major allergen of celery (Apium graveolens), and its immunological and structural relationships to a group of $17-\mathrm{kDa}$ tree pollen allergens," European Journal of Biochemistry, vol. 233, no. 2, pp. 484-489, 1995.

[156] M. Vanek-Krebitz, K. Hoffmann-Sommergruber, M. Laimer da Camara Machado et al., "Cloning and sequencing of Mal d 1, the major allergen from apple (Malus domestica), and its immunological relationship to Bet v 1, the major birch pollen allergen," Biochemical and Biophysical Research Communications, vol. 214, no. 2, pp. 538-551, 1995.

[157] E. Jarolim, M. Tejkl, M. Rohac et al., "Monoclonal antibodies against birch pollen allergens: characterization by immunoblotting and use for single-step affinity purification of the major allergen Bet v I," International Archives of Allergy and Applied Immunology, vol. 90, no. 1, pp. 54-60, 1989.

[158] I. Swoboda, A. Jilek, F. Ferreira et al., "Isoforms of Bet v 1, the major birch pollen allergen, analyzed by liquid chromatography, mass spectrometry, and cDNA cloning," Journal of Biological Chemistry, vol. 270, no. 6, pp. 2607-2613, 1995.
[159] P. Neudecker, K. Schweimer, J. Nerkamp et al., "Allergic crossreactivity made visible. Solution structure of the major cherry allergen Pru av 1," Journal of Biological Chemistry, vol. 276, no. 25, pp. 22756-22763, 2001.

[160] Z. Marković-Housley, A. Basle, S. Padavattan, B. Maderegger, T. Schirmer, and K. Hoffmann-Sommergruber, "Structure of the major carrot allergen Dau c 1," Acta Crystallographica D, vol. 65, part 11, pp. 1206-1212, 2009.

[161] A. Botton, C. Andreotti, G. Costa, and A. Ramina, "Peach (Prunus persica L. Batsch) allergen-encoding genes are developmentally regulated and affected by fruit load and light radiation," Journal of Agricultural and Food Chemistry, vol. 57, no. 2, pp. 724-734, 2009.

[162] F. Karamloo, S. Scheurer, A. Wangorsch, S. May, D. Haustein, and S. Vieths, "Pyr c 1, the major allergen from pear (Pyrus communis), is a new member of the Bet v 1 allergen family," Journal of Chromatography B, vol. 756, no. 1-2, pp. 281-293, 2001.

[163] O. Mirza, A. Henriksen, H. Ipsen et al., "Dominant epitopes and allergic cross-reactivity: complex formation between a Fab fragment of a monoclonal murine IgG antibody and the major allergen from birch pollen bet v 1," Journal of Immunology, vol. 165, no. 1, pp. 331-338, 2000.

[164] M. Berneder, M. Bublin, K. Hoffmann-Sommergruber, T. Hawranek, and R. Lang, "Allergen chip diagnosis for soyallergic patients: Gly m 4 as a marker for severe food-allergic reactions to soy," International Archives of Allergy and Immunology, vol. 161, no. 3, pp. 229-233, 2013.

[165] S. Riecken, B. Lindner, A. Petersen, U. Jappe, and W. M. Becker, "Purification and characterization of natural Ara h 8, the Bet v 1 homologous allergen from peanut, provides a novel isoform," Biological Chemistry, vol. 389, no. 4, pp. 415-423, 2008.

[166] D. Mittag, S. Vieths, L. Vogel et al., "Birch pollen-related food allergy to legumes: identification and characterization of the Bet v 1 homologue in mungbean (Vigna radiata), Vig r 1," Clinical and Experimental Allergy, vol. 35, no. 8, pp. 1049-1055, 2005.

[167] R. Hirschwehr, R. Valenta, C. Ebner et al., "Identification of common allergenic structures in hazel pollen and hazelnuts: a possible explanation for sensitivity to hazelnuts in patients allergic to tree pollen," Journal of Allergy and Clinical Immunology, vol. 90, no. 6, part 1, pp. 927-936, 1992.

[168] R. Hirschwehr, S. Jäger, F. Horak et al., "Allergenss from birch pollen and pollen of the European chestnut share common epitopes," Clinical and Experimental Allergy, vol. 23, no. 9, pp. 755-761, 1993.

[169] M. Gajhede, P. Osmark, F. M. Poulsen et al., "X-ray and NMR structure of bet v 1 , the origin of birch pollen allergy," Nature Structural Biology, vol. 3, no. 12, pp. 1040-1045, 1996.

[170] Z. Marković-Housley, M. Degano, D. Lamba et al., "Crystal structure of a hypoallergenic isoform of the major birch pollen allergen Bet $\mathrm{v} 1$ and its likely biological function as a plant steroid carrier," Journal of Molecular Biology, vol. 325, no. 1, pp. 123-133, 2003.

[171] S. Kofler, C. Asam, U. Eckhard, M. Wallner, F. Ferreira, and H. Brandstetter, "Crystallographically mapped ligand binding differs in high and low IgE binding isoforms of birch pollen allergen Bet v 1," Journal of Molecular Biology, vol. 422, no. 1, pp. 109-123, 2012.

[172] M. D. Spangfort, O. Mirza, H. Ipsen, R. J. J. van Neerven, M. Gajhede, and J. N. Larsen, "Dominating IgE-binding epitope of Bet $\mathrm{v} 1$, the major allergen of birch pollen, characterized by $\mathrm{x}$ ray crystallography and site-directed mutagenesis," Journal of Immunology, vol. 171, no. 6, pp. 3084-3090, 2003. 
[173] P. Neudecker, K. Lehmann, J. Nerkamp et al., "Mutational epitope analysis of Pru av 1 and Api g 1, the major allergens of cherry (Prunus avium) and celery (Apium graveolens): correlating IgE reactivity with three-dimensional structure," Biochemical Journal, vol. 376, part 1, pp. 97-107, 2003.

[174] R. Crameri, "Correlating IgE reactivity with three-dimensional structure," The Biochemical Journal, vol. 376, part 1, pp. el-e2, 2003.

[175] T. Schirmer, K. Hoffimann-Sommergrube, M. Susani, H. Breiteneder, and Z. Marković-Housley, "Crystal structure of the major celery allergen Api g 1: molecular analysis of crossreactivity," Journal of Molecular Biology, vol. 351, no. 5, pp. 11011109, 2005.

[176] R. Fritsch, B. Bohle, U. Vollmann et al., "Bet v 1, the major birch pollen allergen, and Mal d 1, the major apple allergen, crossreact at the level of allergen-specific T helper cells," Journal of Allergy and Clinical Immunology, vol. 102, no. 4, part 1, pp. 679686, 1998 .

[177] D. B. Zilversmit, "Lipid transfer proteins," Journal of Lipid Research, vol. 25, no. 13, pp. 1563-1569, 1984.

[178] J. C. Kader, "Lipid-transfer proteins in plants," Annual Review of Plant Physiology and Plant Molecular Biology, vol. 47, no. 1, pp. 627-654, 1996.

[179] J. Nieuwland, R. Feron, B. A. H. Huisman et al., "Lipid transfer proteins enhance cell wall extension in tobacco," Plant Cell, vol. 17, no. 7, pp. 2009-2019, 2005.

[180] G. Salcedo, R. Sánchez-Monge, D. Barber, and A. Díaz-Perales, "Plant non-specific lipid transfer proteins: an interface between plant defence and human allergy," Biochimica et Biophysica Acta, vol. 1771, no. 6, pp. 781-791, 2007.

[181] R. van Ree, "Clinical importance of non-specific lipid transfer proteins as food allergens," Biochemical Society Transactions, vol. 30, part 6, pp. 910-913, 2002.

[182] E. A. Pastorello, V. Pravettoni, L. Farioli et al., "Clinical role of a lipid transfer protein that acts as a new apple-specific allergen," Journal of Allergy and Clinical Immunology, vol. 104, pp. 10991106, 1999.

[183] E. A. Pastorello, F. P. D’Ambrosio, V. Pravettoni et al., "Evidence for a lipid transfer protein as the major allergen of apricot," Journal of Allergy and Clinical Immunology, vol. 105, no. 2, part 1, pp. 371-377, 2000.

[184] S. Scheurer, I. Lauer, K. Foetisch et al., "Strong allergenicity of Pru av 3, the lipid transfer protein from cherry, is related to high stability against thermal processing and digestion," Journal of Allergy and Clinical Immunology, vol. 114, no. 4, pp. 900-907, 2004.

[185] E. A. Pastorello, L. Farioli, V. Pravettoni et al., "Characterization of the major allergen of plum as a lipid transfer protein," Journal of Chromatography B, vol. 756, no. 1-2, pp. 95-103, 2001.

[186] M. Fernández-Rivas, R. van Ree, and M. Cuevas, "Allergy to Rosaceae fruits without related pollinosis," Journal of Allergy and Clinical Immunology, vol. 100, no. 6, part 1, pp. 728-733, 1997.

[187] N. Pasquato, R. Berni, C. Folli et al., "Crystal structure of peach Pru p 3, the prototypic member of the family of plant non-specific lipid transfer protein pan-allergens," Journal of Molecular Biology, vol. 356, no. 3, pp. 684-694, 2006.

[188] G. García-Casado, L. F. Pacios, A. Díaz-Perales et al., "Identification of IgE-binding epitopes of the major peach allergen Pru p 3," Journal of Allergy and Clinical Immunology, vol. 112, no. 3, pp. 599-605, 2003.
[189] M. Egger, M. Hauser, A. Mari, F. Ferreira, and G. Gadermaier, "The role of lipid transfer proteins in allergic diseases," Current Allergy and Asthma Reports, vol. 10, no. 5, pp. 326-335, 2010.

[190] F. Schocker, D. Lüttkopf, S. Scheurer et al., "Recombinant lipid transfer protein Cor a 8 from hazelnut: a new tool for in vitro diagnosis of potentially severe hazelnut allergy," Journal of Allergy and Clinical Immunology, vol. 113, no. 1, pp. 141-147, 2004.

[191] K. H. Roux, S. S. Teuber, and S. K. Sathe, "Tree nut allergens," International Archives of Allergy and Immunology, vol. 131, no. 4, pp. 234-244, 2003.

[192] E. A. Pastorello, L. Farioli, V. Pravettoni et al., "The maize major allergen, which is responsible for food-induced allergic reactions, is a lipid transfer protein," Journal of Allergy and Clinical Immunology, vol. 106, no. 4, pp. 744-751, 2000.

[193] A. Nemni, J. P. Borges, P. Rougé, A. Barre, and J. Just, “Barley’s lipid transfer protein: a new emerging allergen in pediatric anaphylaxis," Pediatric Allergy and Immunology, vol. 24, no. 4, pp. 410-411, 2013.

[194] P. Colombo, D. Kennedy, T. Ramsdale et al., "Identification of an immunodominant IgE epitope of the Parietaria judaica major allergen," Journal of Immunology, vol. 160, no. 6, pp. 2780-2785, 1998.

[195] D. A. Dempsey, H. Silva, and D. F. Klessig, "Engineering disease and pest resistance in plants," Trends in Microbiology, vol. 6, no. 2, pp. 54-61, 1998.

[196] D. Liu, K. G. Raghothama, P. M. Hasegawa, and R. A. Bressan, "Osmotin overexpression in potato delays development of disease symptoms," Proceedings of the National Academy of Sciences of the United States of America, vol. 91, no. 5, pp. 18881892, 1994.

[197] D. Alexander, R. M. Goodman, M. Gut-Rella et al., "Increased tolerance to two oomycete pathogens in transgenic tobacco expressing pathogenesis-related protein 1a," Proceedings of the National Academy of Sciences of the United States of America, vol. 90, no. 15, pp. 7327-7331, 1993.

[198] V. Balasubramanian, D. Vashisht, J. Cletus, and N. Sakthivel, "Plant $\beta$-1,3-glucanases: their biological functions and transgenic expression against phytopathogenic fungi," Biotechnology Letters, vol. 34, no. 11, pp. 1983-1990, 2012.

[199] A. Anand, T. Zhou, H. N. Trick, B. S. Gill, W. W. Bockus, and S. Muthukrishnan, "Greenhouse and field testing of transgenic wheat plants stably expressing genes for thaumatin-like protein, chitinase and glucanase against Fusarium graminearum," Journal of Experimental Botany, vol. 54, no. 384, pp. 1101-1111, 2003.

[200] G. J. Young, S. Zhang, H. P. Mirsky et al., "Assessment of possible allergenicity of hypothetical ORFs in common food crops using current bioinformatic guidelines and its implications for the safety assessment of GM crops," Food and Chemical Toxicology, vol. 50, no. 10, pp. 3741-3751, 2012.

[201] D. D. Metcalfe, "Genetically modified crops and allergenicity," Nature Immunology, vol. 6, no. 9, pp. 857-860, 2005.

[202] S. L. Taylor, "Protein allergenicity assessment of foods produced through agricultural biotechnology," Annual Review of Pharmacology and Toxicology, vol. 42, pp. 99-112, 2002. 


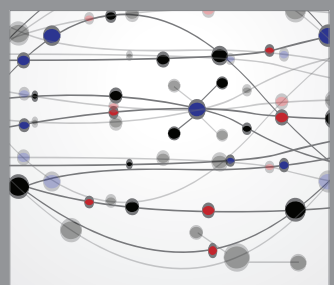

The Scientific World Journal
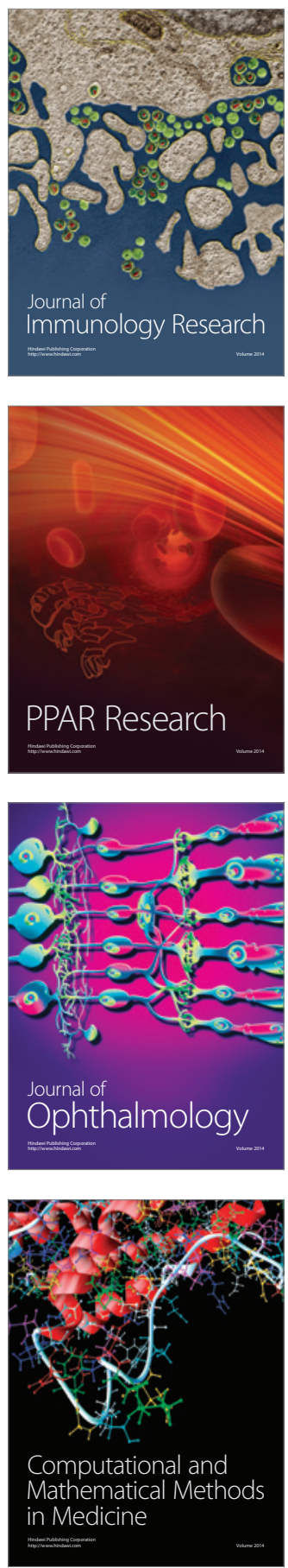

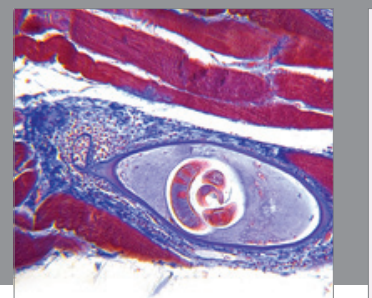

Gastroenterology

Research and Practice
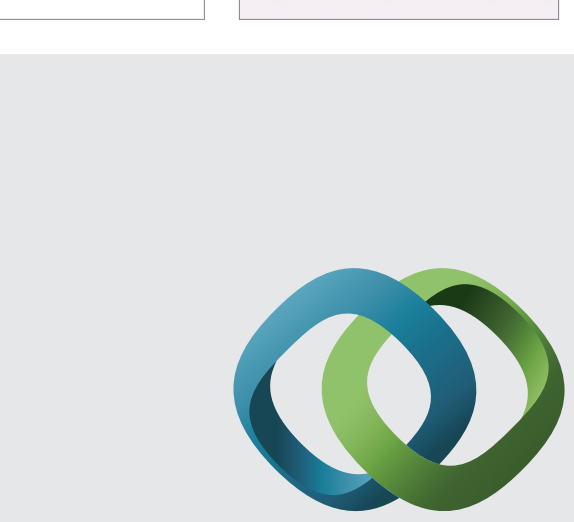

\section{Hindawi}

Submit your manuscripts at

http://www.hindawi.com
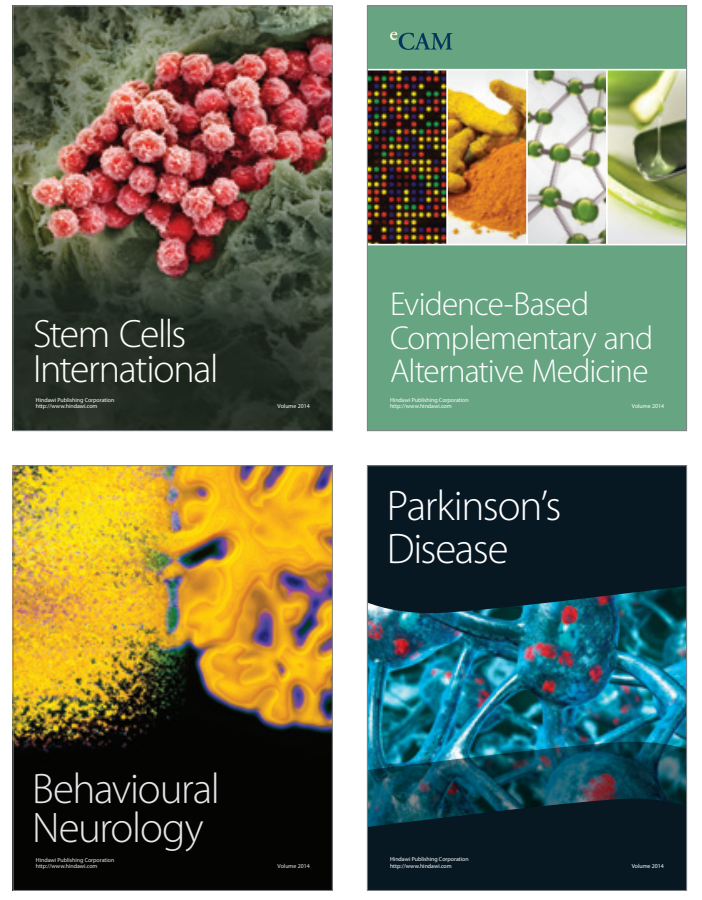
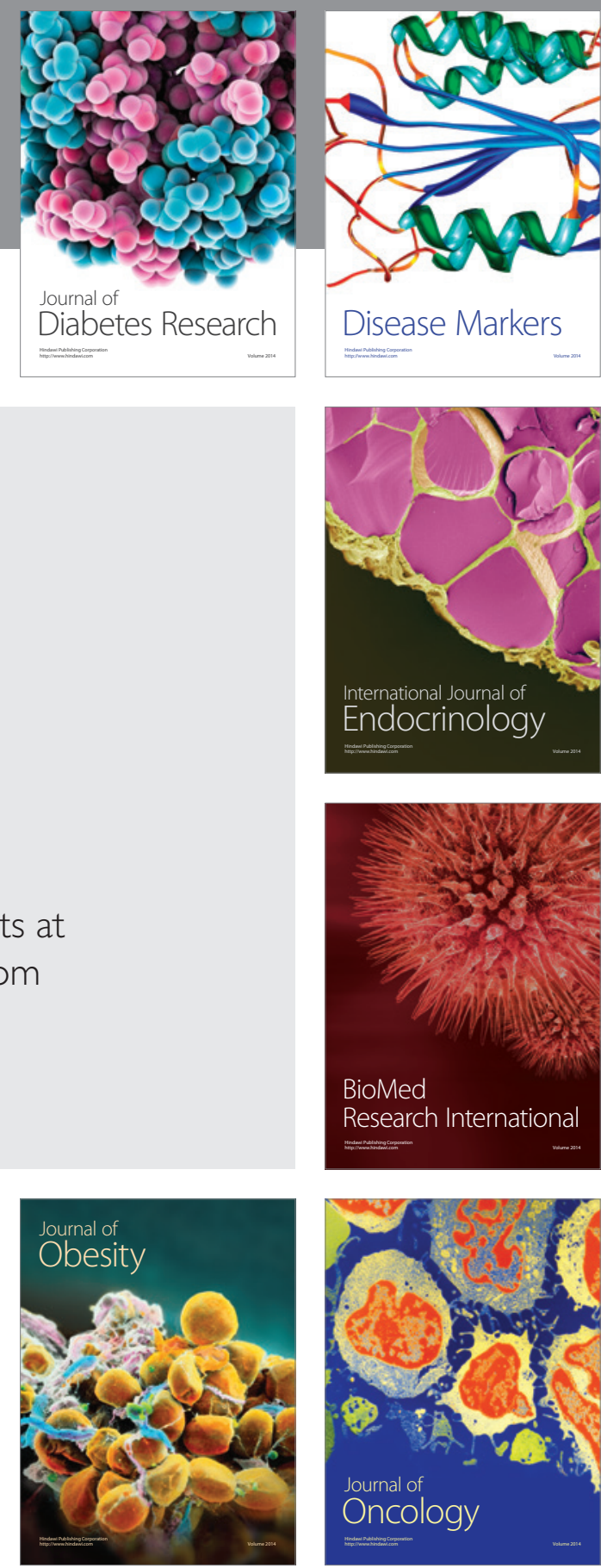

Disease Markers
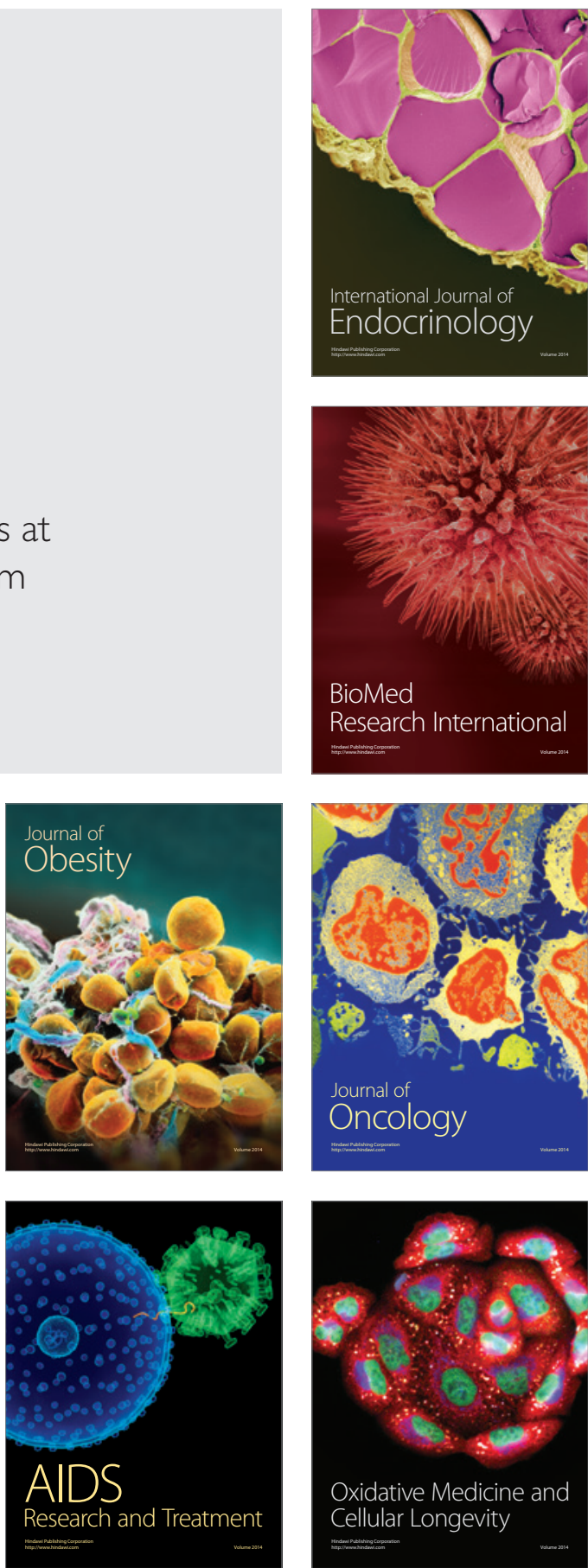